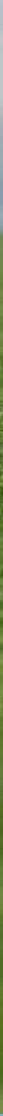

Lange termijn opties voor reductie van broeikasgassen uit de Nederlandse landbouw

Een verkenning

Th.V. Vellinga, J.W. Reijs, J.P. Lesschen, H.R. van Kernebeek

RAPPORT 1133

\title{
WAGENINGEN
}

UNIVERSITY\& RESEARᄃH 



\section{Lange termijn opties voor reductie van broeikasgassen uit de Nederlandse landbouw, een verkenning}

Th.V. Vellinga ${ }^{1}$

J.W. Reijs ${ }^{2}$

J.P. Lesschen ${ }^{3}$

H.R. van Kernebeek ${ }^{1}$

1 Wageningen Livestock Research

2 Wageningen Economic Research

3 Wageningen Environmental Research

Dit onderzoek is uitgevoerd door Wageningen Research, in opdracht van en gefinancierd door het Ministerie van Landbouw, Natuur en Voedselkwaliteit, in het kader van een helpdeskvraag KD-2018-056 "Ondersteuning werkgroep kennis klimaattafel LNV", onderdeel van het programma Duurzame voedselvoorziening en -productieketens \& Natuur (BO-43-012.01-010) 
Vellinga, Th.V., Reijs, J.W., Lesschen, J.P., Van Kernebeek, H.R., 2018. Lange termijn opties voor reductie van broeikasgassen uit de Nederlandse landbouw, een verkenning. Wageningen Livestock Research, Rapport 1133.

\section{Samenvatting}

Het rapport geeft een inschatting van het technisch potentieel van emissiereductie in de gehele productieketen van de Nederlandse landbouw tot het jaar 2050. Vervolgens worden deze ontwikkelingen in een breder kader geplaatst van de transities van consumptie van dierlijke eiwitten, energie en biomassa, het streven naar een circulaire economie en herstel van de biodiversiteit.

\section{Summary}

The report estimates the technical potential mitigation of greenhouse gas emissions up to 2050 of the whole production chain of Dutch agriculture. The mitigation is positioned in the context of the transition of consumption, energy use, biomass and the circular economy and the improvement of biodiversity.

Dit rapport is gratis te downloaden op https://doi.org/10.18174/463949 of op www.wur.nl/livestock-research (onder Wageningen Livestock Research publicaties).

(C) 2018 Wageningen Livestock Research

Postbus 338, 6700 AH Wageningen, T 03174839 53, E info.livestockresearch@wur.nl, www.wur.nl/livestock-research. Wageningen Livestock Research is onderdeel van Wageningen University \& Research.

Wageningen Livestock Research aanvaardt geen aansprakelijkheid voor eventuele schade voortvloeiend uit het gebruik van de resultaten van dit onderzoek of de toepassing van de adviezen.

Alle rechten voorbehouden. Niets uit deze uitgave mag worden vermenigvuldigd en/of openbaar gemaakt worden door middel van druk, fotokopie, microfilm of op welke wijze dan ook zonder voorafgaande toestemming van de uitgever of auteur.

Wageningen Livestock Research is NEN-EN-ISO 9001:2015 gecertificeerd.

Op al onze onderzoeksopdrachten zijn de Algemene Voorwaarden van de Animal Sciences Group van toepassing. Deze zijn gedeponeerd bij de Arrondissementsrechtbank Zwolle. 


\section{Inhoud}

Woord vooraf

$\begin{array}{ll}\text { Samenvatting } & 7\end{array}$

1

Introductie

11

1.1 Aanleiding $\quad 11$

1.2 Doelstelling $\quad 11$

1.3 Aanpak 11

$\begin{array}{ll}\text { Huidige emissies } & 13\end{array}$

2.1 Werkwijze $\quad 13$

2.2 Emissies volgens NIR en ketenbenadering 13

$3 \quad$ Mitigatie strategieën voor $2050 \quad 16$

$3.1 \quad$ Klimaatdoelen voor $2050 \quad 16$

3.2 Mitigatiestrategieën richting 2050: meer dan efficiëntieverbetering 17

3.3 Ingrijpen op emissiebronnen als basis voor toekomstige reductiestrategie 18

3.3.1 Vermindering van methaan uit de pens 19

3.3.2 Vermindering van methaan en lachgas uit stal en mestopslag 20

3.3.3 Vermindering van lachgas bij de aanwending van mest en kunstmest $\quad 20$

3.3.4 C-vastlegging en emissies in en uit de bodem 21

$\begin{array}{ll}3.3 .5 \text { Glastuinbouw } & 23\end{array}$

3.3.6 Verdergaande technologische maatregelen in plantaardige en dierlijke productie? $\quad 23$

3.4 Emissiereducties buiten het primaire bedrijf en van energie 23

4

$\begin{array}{ll}\text { Emissiereducties in } 2050 & 25\end{array}$

$4.1 \quad$ Reductie van bronemissies $\quad 25$

4.2 De optie van $100 \%$ afgesloten stallen $\quad 25$

4.3 Productie van energie als mitigatie en compensatie? 26

$\begin{array}{llr}5 & \text { Implementatie van de maatregelen } & 27\end{array}$

6 De resultaten in een breder kader $\quad 28$

6.1 De ruimte voor landbouw in Nederland. 28

6.2 De relatie tussen productie en consumptie in Nederland 28

6.3 Vraag naar biomassa en ruimte neemt toe: grond is schaars 29

Literatuur 32

Bijlage 1 Uitwerking reductie broeikasgasemissies van de Nederlandse landbouw per onderdeel

Bijlage 2 Berekening broeikasgasemissies op keten niveau van de veehouderij in Nederland, gebaseerd op dieraantallen 2017

Bijlage 3 Tabellen voor de inschatting van de implementatie van maatregelen 37

Bijlage 4 Efficiëntieverbetering in de Nederlandse veehouderij 



\section{Woord vooraf}

Deze verkenning is opgesteld door een projectteam bestaande uit Theun Vellinga en Heleen van Kernebeek (Wageningen Livestock Research), Jan Peter Lesschen (Wageningen Environmental Research) en Joan Reijs (Wageningen Economic Research)en. Het werk zou echter niet mogelijk zijn geweest zonder de hulp van vele collega's bij Wageningen Universiteit en Research: André Bannink, Karin Groenestein, André Aarnink, Gerard Velthof, Wijnand Sukkel, Henri Prins, Ruud van der Meer, Hilko Ellen, Yvette de Haas, Marion de Vries, Roel Jongeneel, Michiel van Galen, Nico van der Velden, Andries Visser, Bastiaan Meerburg en Geert van der Peet.

Wij zijn hen zeer erkentelijk voor alle hulp. 


\section{Samenvatting}

De klimaattafel landbouw en landgebruik heeft in het voorjaar van 2018 de opdracht gekregen om plannen te ontwikkelen voor de reductie van broeikasgassen met 3,5 Megaton in 2030. Binnen die opdracht is een werkgroep "Kennis en innovatie" aan de slag gegaan om de lange termijn mogelijkheden van verdere reductie van broeikasgassen te verkennen.

Een team van onderzoekers uit Wageningen is gevraagd om een verkenning uit te voeren van het technisch reductiepotentieel in de gehele productieketen. Het team heeft op basis van kennis van onderzoekers aangegeven wat mogelijke stappen zijn om de emissie van broeikasgassen verder te reduceren. Daarbij is niet gekeken naar de mate waarin dit wordt geïmplementeerd in de landbouw en ook niet naar de effecten voor de nationale economie of het bedrijfsinkomen. Vervolgens is de klimaatopgave in een breder kader geplaatst van de energietransitie, de biomassa- en voedseltransitie en het deltaplan biodiversiteitsherstel. Vanwege de korte doorlooptijd is de studie op te vatten als een verkenning van technische mogelijkheden, waarvan veel onderdelen nog verder uitgewerkt kunnen worden. De huidige grootte van de veestapel is als vertrekpunt in de berekeningen gebruikt en constant verondersteld richting 2050, zodat effecten van reductiemaatregelen helder in beeld komen ten opzichte van de huidige situatie.

De huidige broeikasgasemissies van de Nederlandse landbouw en het landgebruik bedragen in 2017 op keten niveau bijna 54 Megaton $\mathrm{CO}_{2}$ equivalenten. Deze hoeveelheid valt uiteen in drie grote brokken: a) de zogeheten "overige broeikasgassen landbouw", methaan en lachgas, in totaal 18,7 Megaton; b) overige landbouw-gerelateerde emissies in Nederland (met name landgebruik en energiegebruik door de landbouw, inclusief glastuinbouw, in totaal 19,3 Megaton; en c) emissies gerelateerd aan de productie van grondstoffen (met name diervoeder) in het buitenland, inclusief de bijbehorende emissies van landgebruiksverandering, in totaal 15,5 Megaton.

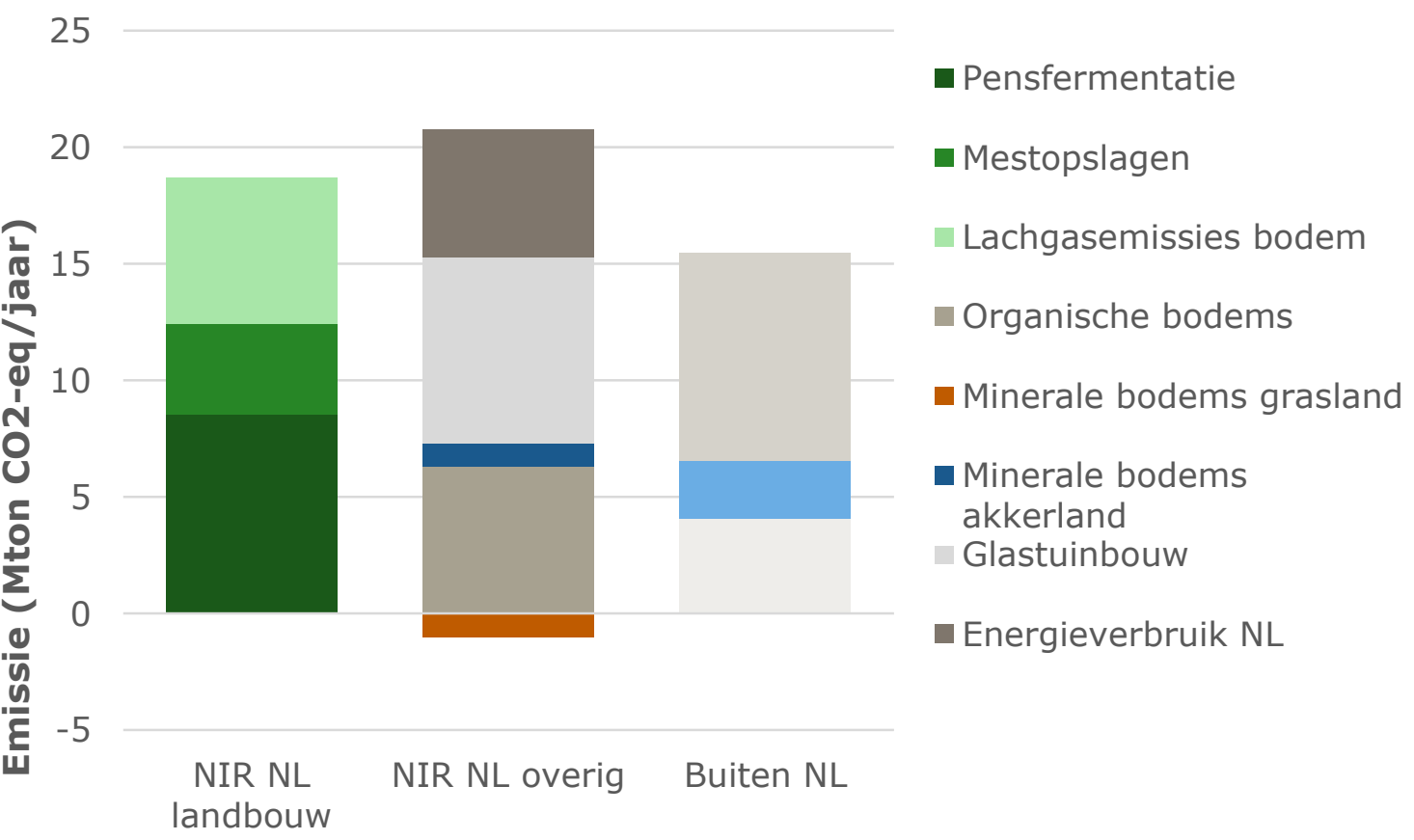

Figuur 1 Broeikasgasemissies in de categorie "overige broeikasgassen (niet $\mathrm{CO}_{2}$ ) landbouw", (NIR NL landbouw) de $\mathrm{CO}_{2}$-emissies die afkomstig zijn van landbouw en landgebruik volgens de nationale emissieregistratie (NIR NL overig) en de broeikasgasemissies die bij de landbouw productie keten horen, maar buiten de nationale emissieregistratie vallen. 
Broeikasgasemissies uit de landbouw zijn sinds de jaren negentig aanzienlijk gedaald. Deze daling is gelijk op gelopen met de verbetering van de productie-efficiëntie in de landbouw. Dat is vooral een gevolg van de melkquotering en het mestbeleid, voortkomend uit de Nitraatrichtlijn, de Kaderrichtlijn Water en het emissieplafond voor ammoniak. In laatste jaren stagneert de daling van de emissies. Reductie van broeikasgassen kan via vier hoofdsporen, verbetering van de productie-efficiëntie, aanpak van emissiebronnen, end-of-pipe maatregelen en structurele maatregelen (binnen en buiten systeem). Voor de lange termijn verkenning is bewust geen verdere opvoering van de productieefficiëntie meegenomen. $\mathrm{Er}$ is in dat spoor al veel laaghangend fruit geplukt, er is sprake van afnemende meeropbrengsten bij verdergaande inspanningen, het vergt erg veel kennis en inzet van de landbouwers, het heeft het risico in zich de landbouw verder af te brengen van andere duurzaamheidsdoelen (sluiten kringlopen, biodiversiteit) en maatschappelijk gewenste ontwikkelingen (dierenwelzijn) en het kan op gespannen voet staan met de noodzaak om te komen tot robuuste productiesystemen om in te spelen op een veranderend klimaat.

Voor de lange termijn verkenning is ingezet op aanpak van emissiebronnen en deels op end-of-pipe oplossingen in het productiesysteem. Dit heeft geleid tot het volgende technische reductiepotentieel:

a) methaan uit de pens: fokkerij, voeding en toevoegmiddelen: mogelijke reductie $50 \%$;

b) scheiding mest en urine in stallen, volledig afgesloten opslagen, verwerking gassen: mogelijke reductie $75 \%$,

c) aanwending mest en kunstmest, inzet vlinderbloemigen, aangepaste bemesting, inzet nitrificatieremmers: mogelijke reductie $44 \%$,

d) emissies landbouwgronden, vernatten veen, onderwaterdrainage, management gras- en bouwland en ander landgebruik zoals agroforestry. Mogelijke 3,2 Megaton;

e) Voor de glastuinbouw $n$ het overig energiegebruik zijn de $\mathrm{CO}_{2}$ emissies volledig op nul gezet, uitgaande van een volledige energietransitie naar hernieuwbare energie. Het energiegebruik binnen de landbouw kan worden opgevangen door zonnepanelen en windturbines.

Door toepassing van de maatregelen kunnen de totale emissies op keten niveau worden teruggebracht van 53,5 tot 10,9 Megaton. In de drie hoofdgroepen: "overige broeikasgassen landbouw", een daling van 18,7 naar 9,2 Megaton; bij de emissies van landgebruik en energie van 19,3 naar 0 Megaton en bij de emissies gerelateerd aan de productie van diervoeder grondstoffen in het buitenland een daling van 15,5 naar 1,7 Megaton. Of deze emissiereductie voldoende is om met de huidige omvang de beleidsdoelen in 2050 te realiseren, hangt af van het gekozen beleidsscenario. Bij een streng beleidsscenario is aanvullende reductie nodig.

De toepasbaarheid van de maatregelen is ingeschat aan de hand van technische beschikbaar (het Technical Readiness Level, TRL), de maatschappelijke acceptatie, de kosten en de mate waarin systeemveranderingen nodig zijn. Er zijn veel maatregelen die al (bijna) toepasbaar zijn. Er zijn al middelen en methoden beschikbaar om methaan en lachgas in mest en bodem te verminderen. Daar zijn wel kosten aan verbonden, maar daar staan geen meeropbrengsten tegenover. Datzelfde geldt voor onderwaterdrainage in veenweidegebieden. Het gebruik van toevoegmiddelen roept ook maatschappelijke weerstand op. Verdergaande maatregelen zoals fokkerij en nieuwe toevoegmiddelen om methaan uit pensfermentatie te reduceren of lachgas uit bodem en mest te reduceren vergen nog een ontwikkelingstraject. De ontwikkeling van zogeheten nul-emissiestallen is al gaande, de toepassing daarvan is op kortere termijn mogelijk. Een verdergaande stap naar volledige scheiding van mest en urine is een grotere systeemaanpassing, omdat het ingrijpt op stallen, opslagen en appratuur voor aanwending van mest. Een overkoepelend vraagstuk is het ontwikkelen van meer fundamenteel inzicht in de koolstof en stikstof-dynamiek in bodem, mest en biomassa. Dergelijk onderzoek kan richting geven aan de benodigde innovaties.

De overgang naar een landbouw met een sterke gereduceerde emissie kan niet los worden gezien van vier belangrijke transities die tegelijkertijd plaatsvinden en er deels ook aan gerelateerd zijn: a) de verandering van de consumptie van dierlijke eiwitten; b) de energietransitie, die men deels uit biomassa wil halen; c) het gebruik van biomassa als industriële grondstof in plaats van olie; en d) het besef dat grondstoffen eindig zijn leidt tot de omvorming naar een circulaire economie, waarvan kringlooplandbouw een onderdeel is. Tegelijk is het nodig dat actief wordt gewerkt aan behoud en herstel van de biodiversiteit. Deze transities leiden tot een sterke verandering en per saldo een toename van de vraag naar biomassa, wat zal leiden tot een toename van de druk op grondgebruik, 
zowel binnen als buiten Nederland. Anderzijds zal het streven naar biodiversiteitsherstel leiden tot een behoefte aan een lagere intensiteit van het grondgebruik. Dat kan leiden tot spanningen die opgelost moeten worden door een combinatie van publieke en private sturing en technische innovaties. Op basis van deze verkenning zijn de volgende conclusies geformuleerd:

1. $\mathrm{Er}$ is op basis van de huidige kennis, inzichten en verwachtingen in wetenschappelijk onderzoek een forse technische potentie voor reductie van broeikasgasemissies uit de Nederlandse landbouw en landgebruik op de lange termijn.

2. Om deze reductie te bereiken is veel meer nodig dan het voortzetten van het efficiëntiespoor. De reductie kan worden gerealiseerd door aanpak van emissiebronnen zelf (methaan pens, mest, lachgasvorming) met steeds verder afnemend gebruik van end-of-pipe methoden (afvangen emissies mest).

3. Het reductiepotentieel in de gehele productieketen, met name de productie van veevoer en kunstmest, binnen en buiten Nederland is veel groter dan alleen in de primaire productie in Nederland.

4. Een aantal voorgestelde maatregelen zijn bijna praktijkrijp, de toepassing ervan wordt belemmerd door kosten, kennis, concurrentie om grond en maatschappelijke acceptatie. Een grootschalig introductieprogramma kan zorgen voor versnelling.

5. In de landbouw ligt een forse reductieopgave met betrekking tot energiegebruik maar deze valt niet binnen de NIR-landbouw. De uitdaging hoe deze energietransitie in de landbouw georganiseerd moet en kan worden en hoe deze inspanning van de landbouw zichtbaar wordt in emissierapportages.

6. De opgave van vermindering van emissies kan niet los worden gezien van vier grote transities waar de Nederlandse landbouw en voedselproductie mee te maken heeft: energie, eiwit, biobased economie en circulaire economie. Klimaat en de vier genoemde transities leiden samen tot een veranderende en waarschijnlijk groeiende vraag naar biomassa en land.

7. De grote opgaven voor de lange termijn liggen in

a. Transitie, governance en beleid: hoe komen tot een proces waarin een goede afweging kan plaatsvinden tussen economische en publieke belangen bij het sturen van veranderend landgebruik, productie van biomassa en een klimaatbestendig landschap

b. Techniek: Het ontwikkelen van innovaties waarmee productie van biomassa, een vergaande reductie van emissies van methaan en lachgas en voortgaande vastlegging van koolstof in landbouw- en natuurgronden in de praktijk mogelijk worden zonder negatieve gevolgen voor andere doelen. 


\section{$1 \quad$ Introductie}

\section{$1.1 \quad$ Aanleiding}

In december 2015 is op de klimaattop in Parijs door 195 landen het 'Klimaatakkoord van Parijs' ondertekend. Ook Nederland ondertekende dat akkoord en stemde daarmee in de opwarming van de aarde beperken tot ruim onder 2 graden Celsius, met een streven van een maximale opwarming van 1,5 graden Celsius ten opzichte van pre-industriële niveaus. Elk land moet nu zijn eigen, nationale maatregelen nemen om het wereldwijd afgesproken doel te halen. In Nederland is hiervoor in 2018 gestart met klimaattafels ${ }^{1}$, waarbij overheden, bedrijfsleven en maatschappelijke partijen gezamenlijk streven naar het sluiten van een klimaatakkoord. In dit klimaatakkoord moeten concrete afspraken worden gemaakt over de maatregelen waarmee we de broeikasgasuitstoot in Nederland kan worden gehalveerd.

De klimaattafel "landbouw en landgebruik" heeft in het voorjaar van 2018 de opdracht gekregen om plannen te ontwikkelen voor de reductie van de emissie van broeikasgassen met 3.5 Megaton tot 2030. Voor de uitwerking van die opgave zijn een aantal werkgroepen ingesteld. Eén van deze is de werkgroep "Kennis en Innovatie" die de opdracht had om de mogelijkheden van emissiereductie uit de Nederlandse landbouw en landgebruik op lange termijn te verkennen en daaruit innovatieopgaven te destilleren. Een team van onderzoekers van Wageningen Universiteit en Research heeft ondersteuning geboden aan de werkgroep.

\subsection{Doelstelling}

Het team van Wageningen Universiteit en Research is gevraagd om een verkenning te maken van het technische reductiepotentieel van broeikasgasmaatregelen in 2050, geredeneerd vanuit de huidige situatie. Hierbij is vanaf het begin aangegeven dat de maatregelen zich niet alleen moeten beperken tot de broeikasgasemissies in de categorie landbouw en landgebruik, landgebruiksverandering en bosbouw (de z.g. LULUCF) in Nederland maar dat alle emissies op het primaire bedrijf inclusief de productie van grondstoffen (bijvoorbeeld kunstmest en krachtvoer) moeten worden meegenomen. In vaktermen wordt dit aangeduid als cradle-to-farm-gate (van de oorsprong van de grondstof tot en met de "achterdeur" van de boerderij waar het landbouwproduct het bedrijf verlaat). Emissies na de boerderij (bijvoorbeeld als gevolg van verwerking, transport, bewaring en verpakking en bij consument en retail) zijn buiten beschouwing gelaten.

\subsection{Aanpak}

De analyse is in stappen uitgevoerd. Eerst is in beeld gebracht wat de geschatte emissies zijn in 2017, zowel op basis van de National Inventory Reports die voor de IPCC worden opgesteld, als op basis van de emissies in de gehele keten. Daarna is op basis van beschikbare kennis en inzicht van experts een inschatting gemaakt van het reductiepotentieel van emissie reducerende maatregelen op landbouwbedrijven. Vervolgens is het palet aan maatregelen gerangschikt op basis van de huidige toepasbaarheid in de praktijk.

Tenslotte is de reductieopgave in een breder kader geplaatst van de veranderende vraag naar biomassa en wordt beschreven wat deze vraag betekent voor de innovatieopgave.

In de hier uitgevoerde berekeningen gaan we uit van de huidige grootte van de sectoren. Dat is niet omdat deze niet ter discussie mag staan, maar om een vergelijking te kunnen maken ten opzichte van de huidige situatie. Het geeft zo meer inzicht in de mate van reductie die mogelijk is.

Er wordt geen inschatting gemaakt van de economische kosten en baten van alle maatregelen die bijdragen aan het reductiepotentieel. De huidige kosten-baten afweging die wordt toegepast in korte

\footnotetext{
${ }^{1}$ https://www.klimaatakkoord.nl/
} 
termijn verkenningen, gebeurt in de context van het bedrijfsniveau. De grootte van de sector is daarbij geen factor. Bij een sterke reductiedoelstelling en een lange termijn perspectief zal ook het productievolume van de landbouw en de verhouding tussen sectoren ter discussie komen staan. De kosten baten afweging moet dan gebeuren in de context van bedrijfs- en sectorniveau. Dat is een studie op zich, die niet past binnen het korte tijdsbestek en die ook geen onderdeel was van de opdracht van de werkgroep Innovatie. 


\section{$2 \quad$ Huidige emissies}

\section{$2.1 \quad$ Werkwijze}

De berekening van de emissies in 2017 is gebaseerd op een combinatie van emissiecijfers en eigen berekeningen.

- De emissiecijfers van 2016 uit de nationale emissierapportage (aangeduid als National Inventory Report, NIR; Coenen et al., 2018) zijn de basis geweest voor de emissies op het primaire bedrijf. Deze zijn ontleend aan de berekeningen met het Nederlandse emissiemodel voor de landbouw NEMA (Vonk et al., 2018)

- De NIR 2018 (Coenen et al., 2018) is ook de basis geweest voor de emissies die voortkomen uit landgebruik en verandering in landgebruik, de zogenaamde emissiesector LULUCF, land use, land use change and forestry.

- Met name in de melkveehouderij veranderden de dieraantallen in 2017 relatief sterk als gevolg van de eerdere uitbreiding van de veestapel na het einde van het melkquotum, de bijbehorende overschrijding van de maximaal toelaatbare fosfaatuitscheiding en de daaropvolgende inkrimping van de melkveestapel. Daarom zijn de emissies van 2016 aangepast aan de dieraantallen van 2017. De bron voor de dieraantallen is de Landbouwtelling van 2017 (CBS, 2017).

- De overige emissiecijfers in de gehele productieketen van plantaardige en dierlijke producten zijn gebaseerd op a) de berekeningen met het rekenprogramma FeedPrint (Vellinga et al., 2012), dat een levenscyclusanalyse bevat van alle veevoedergrondstoffen en de belangrijkste Nederlandse akkerbouwgewassen; b) de gegevens over gebruik van meststoffen in de Nederlandse landbouw (Vonk et al., 2018) en; c) inschattingen van de invoer van met name veevoergrondstoffen vanuit de EU en daarbuiten.

- De Nationale Energieverkenning (PBL, 2017) is de basis voor de inschatting van de emissie uit energiegebruik in de Nederlandse landbouw.

\subsection{Emissies volgens NIR en ketenbenadering}

Op basis van de gehanteerde rekenwijze bedraagt de voorspelde totale emissies van de landbouw voor de overige broeikasgassen (OBKG) methaan en lachgas voor het jaar 201718.7 Megaton $\mathrm{CO}_{2}$ equivalenten. Ruim $90 \%$ van deze emissie is afkomstig van de veehouderij, zowel van herkauwers (vooral melkvee) als van éénmagige dieren.

Voor de glastuinbouw is een emissie van 5.6 Megaton $\mathrm{CO}_{2}$ equivalenten aangehouden (Van der Velden en Smit, 2017), terwijl de emissies voor LULUCF voor landbouw en natuur respectievelijk uitkomen op 6.3 en 1.6 Megaton $\mathrm{CO}_{2}$ equivalenten. Buiten de directe landbouw wordt nog een emissie gerealiseerd van 9.5 Megaton voor energiegebruik van de landbouw binnen Nederland (de categorieën 2.1 en 2.2). De totale emissies die gerelateerd zijn aan landbouw en landgebruik, maar buiten de categorie OBKG landbouw vallen, zijn in totaal 19.8 Megaton $\mathrm{CO}_{2}$-equivalenten. Buiten Nederland is er nog een emissie van $4.0+2.4+8.9=15.3$ Megaton, wat afkomstig is van de buitenlandse productie van veevoergrondstoffen (Tabel 1 en Figuur 2).

Het verschil tussen de sectorale benadering en de ketenbenadering is groot bij de dierlijke productieketens. De emissies op keten niveau zijn het dubbele ten opzichte van de NIR-landbouw en landgebruik. Het aandeel van de emissies buiten het primaire bedrijf is vooral groot bij de éénmagige dieren (zie Figuur 3). Deze zijn sterk afhankelijk van geïmporteerd veevoer.

Een gedetailleerde uitwerking van de berekening is te vinden in bijlage 1. 
Tabel 1 De broeikasgasemissies in Megaton $\mathrm{CO}_{2}$-equivalenten voor het jaar 2017, gebaseerd op cijfers van 2016 en dieraantallen van 2017. Bron NIR 2016 en cijfers CBS over 2017. Een negatief getal betekent een vastlegging.

\begin{tabular}{|c|c|c|}
\hline $\begin{array}{l}\text { Plek in nationaal } \\
\text { systeem }\end{array}$ & Activiteit / emissiebron & $\begin{array}{l}\text { Prognose } 2017 \\
\text { (Mton } \mathrm{CO}_{2} \text { eq) }\end{array}$ \\
\hline \multirow[t]{3}{*}{ 1.1 Landbouw OBKG } & 1.1.1 Pens en darmfermentatie (methaan) & 8.5 \\
\hline & 1.1.2 Mestopslagen (methaan en lachgas) & 3.9 \\
\hline & 1.1.3 Mestaanwending en bodem (lachgas) & 6.3 \\
\hline \multicolumn{2}{|c|}{ Totaal landbouw overige broeikasgassen in Nederland } & 18.7 \\
\hline 1.2 Landbouw $\mathrm{CO}_{2}$ & 1.2.1 Glastuinbouw & 5.6 \\
\hline \multirow[t]{2}{*}{1.3 LULUCF } & 1.3.1 LULUCF landbouw gerelateerd & 6.3 \\
\hline & 1.3.2 LULUCF Natuur & -1.6 \\
\hline \multirow[t]{2}{*}{ 2.1 Transport/Energie } & 2.1.1 Energiegebruik NL landbouw (diesel NL ) & 1.3 \\
\hline & $\begin{array}{l}\text { 2.1.1 Energiegebruik NL landbouw (elektriciteit, } \\
\text { kunstmestproductie) }\end{array}$ & 1.5 \\
\hline 2.2 Industrie & 2.2.1 Energiegebruik (kunstmest, mengvoer) $\left(\mathrm{CO}_{2}\right.$ en lachgas)* & 6.2 \\
\hline \multicolumn{2}{|c|}{ Totaal $\mathrm{CO}_{2}$ en LULUCF toegeschreven aan landbouw en landgebruik in NL } & 19.3 \\
\hline \multicolumn{2}{|c|}{ Totaal Landbouw en landgebruik binnen Nederland } & $\mathbf{3 8 . 0}$ \\
\hline \multirow{3}{*}{$\begin{array}{l}3.1 \text { Overige emissies in } \\
\text { de keten }\end{array}$} & 3.1.1 Teelt voergrondstoffen buiten Nederland $\left(\mathrm{CO}_{2}\right)$ & 4.1 \\
\hline & 3.1.2 Teelt voergrondstoffen buiten NL (methaan en lachgas) & 2.5 \\
\hline & 3.1.3 Teelt voergrondstoffen (LULUCF) & 8.9 \\
\hline \multicolumn{2}{|c|}{ Totaal emissies in de keten buiten Nederland } & 15.5 \\
\hline \multicolumn{2}{|c|}{ Totaal volgens ketenbenadering } & 53.5 \\
\hline
\end{tabular}

*) op basis van een inschatting van het in Nederland gebruikte deel van de Nederlandse kunstmest- en krachtvoerproductie. Zie bijlage 2

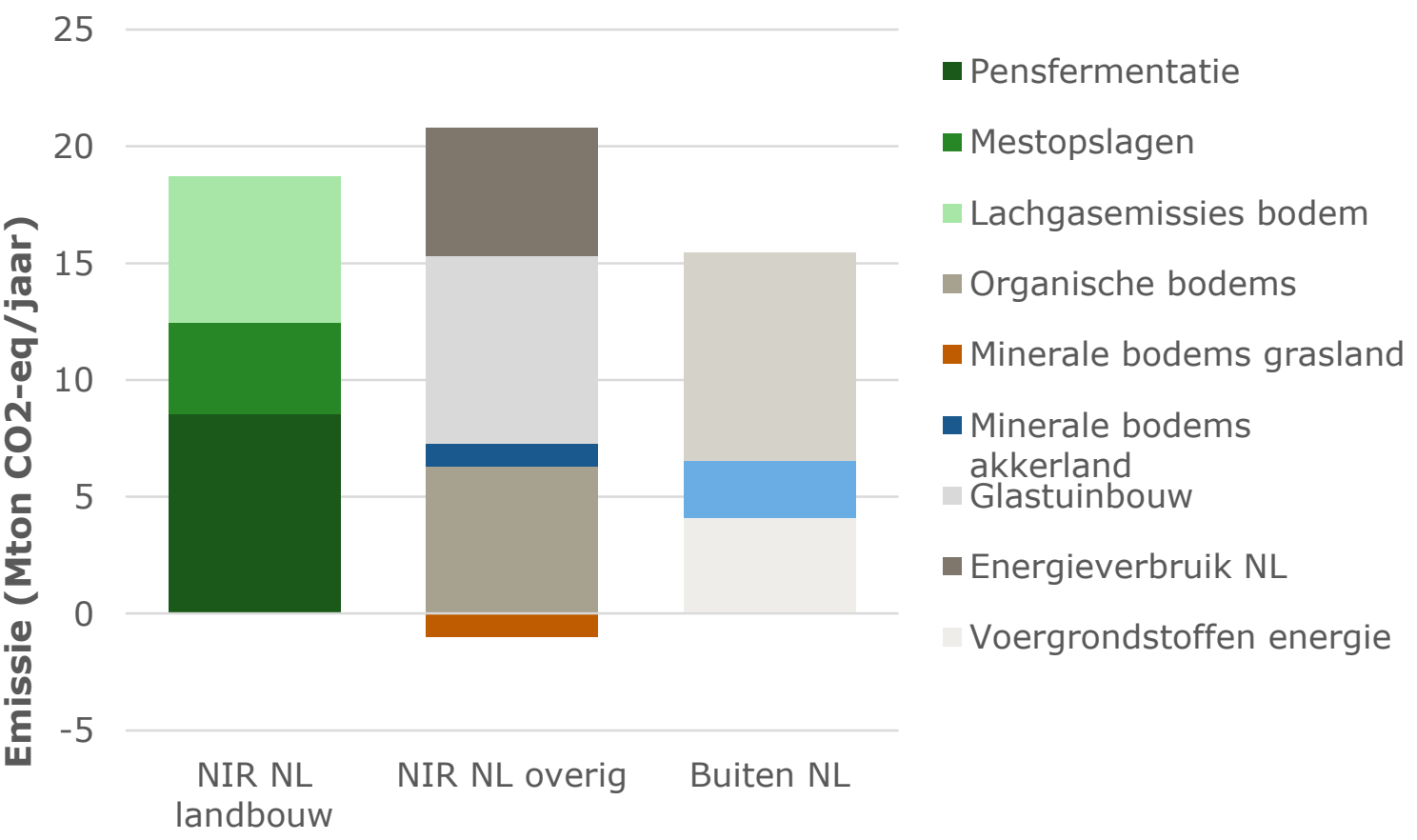

Figuur 2 Broeikasgasemissies in de categorie "overige broeikasgassen (niet $\mathrm{CO}_{2}$ ) landbouw", (NIR $\mathrm{NL}$ landbouw) de $\mathrm{CO}_{2}$-emissies die afkomstig zijn van landbouw en landgebruik volgens de nationale emissieregistratie (NIR NL overig) en de broeikasgasemissies die bij de landbouw productie keten horen, maar buiten de nationale emissieregistratie vallen. 


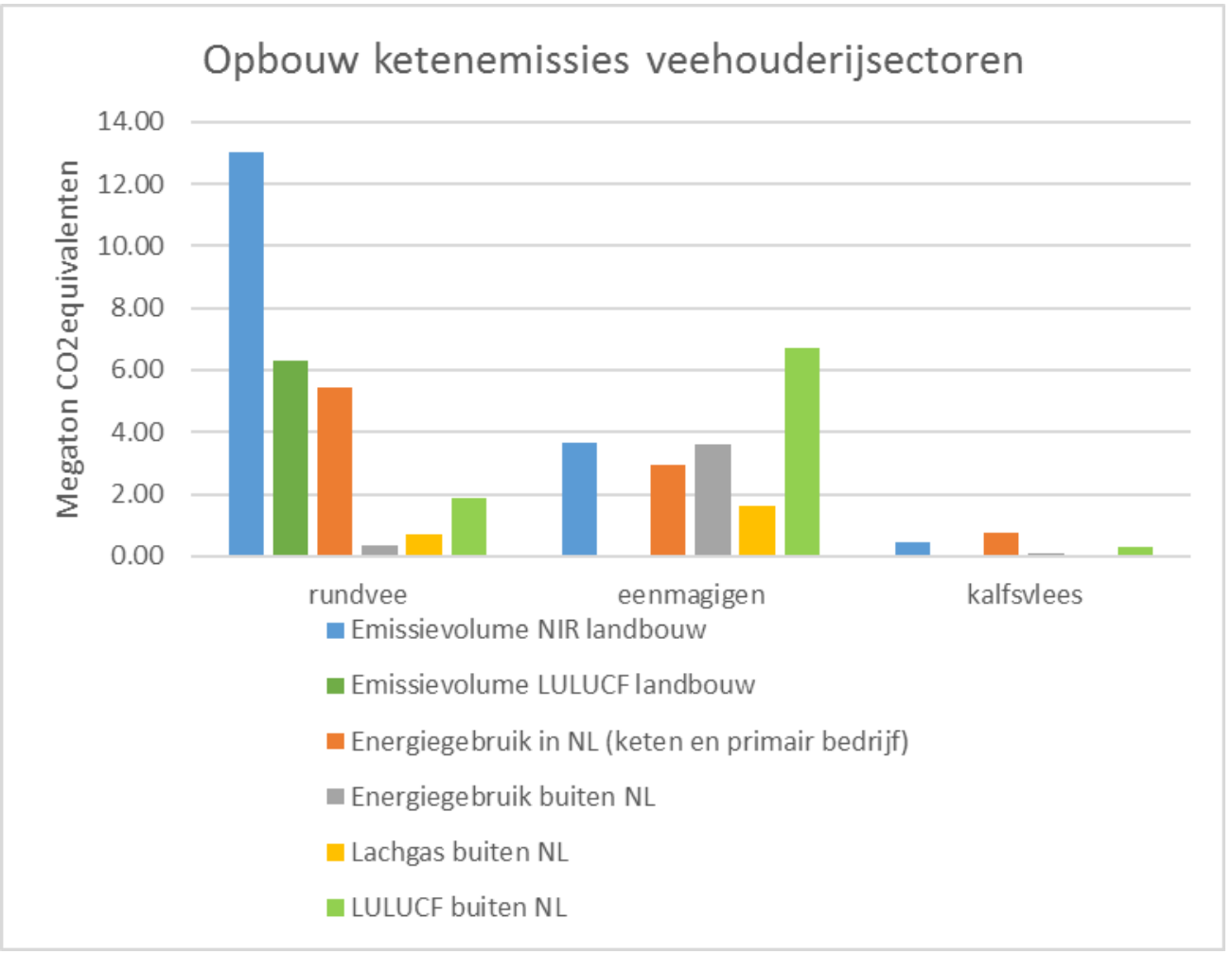

Figuur 3 De broeikasgasemissies in de gehele productieketen van rundvee, éénmagige dieren (varkens, kippen) en vleeskalveren die in Nederland worden gehouden. 


\section{Mitigatie strategieën voor 2050}

\section{$3.1 \quad$ Klimaatdoelen voor 2050}

Om het mogelijke effect van huidige klimaatdoelen in 2050 te illustreren, zijn verschillende scenario's uitgewerkt van het toegestane emissievolume in 2050. Het meest verstrekkende betreft het scenario dat voortkomt uit het akkoord van Parijs. Daar is afgesproken dat de opwarming maximaal 2 graden Celsius mag zijn en het streven naar een maximale opwarming van 1,5 graden. Een specifieke reductiedoelstelling voor 2050 is niet vastgelegd, maar een emissiereductie de orde grootte van $95 \%$ ten opzichte van de emissies in het referentiejaar 1990 zal nodig zijn. Dat is ook het scenario dat wordt gehanteerd in het recente rapport van de Raad voor de Leefomgeving en Infrastructuur (RLI, 2018). De totale mogelijke uitstoot voor Nederland als geheel bedraagt in dat geval $11,2 \mathrm{Megaton} \mathrm{CO}_{2}$ equivalenten per jaar in 2050. Dit scenario is uitgewerkt in twee varianten: de variant ' $100 \%$ landbouw' gaat ervan uit dat deze 11,2 Megaton geheel van de landbouw afkomstig zal zijn. De variant ' $1 / 3^{e}$ landbouw' gaat ervan uit dat een derde van alle emissies in 2050 van de landbouw afkomstig zullen zijn en dat de overige emissieruimte zal worden gevuld door andere sectoren. In eerdere stukken heeft de Europese Unie in de "Low Carbon Roadmap 2050"

(http://www.roadmap2050.eu) een reductie van $80 \%$ aangehouden. In de toelichting op de Roadmap heeft de EU aangegeven te verwachten dat het aandeel van de landbouw in de totale emissies dan ongeveer een derde deel van het totaal zal zijn, omdat de wereldwijde vraag naar voedsel toeneemt en omdat de landbouw haar emissies niet terug kan brengen naar nul. In de Nederlandse uitwerking voor de Carbon Roadmap (Eerste Kamer, 2011) is voor de landbouw uitgegaan van een bandbreedte in emissiereductie tussen de $42 \%$ en $49 \%$ van de emissie in 1990 om in het geheel aan deze $80 \%$ te komen. Deze $42 \%$ en $49 \%$ zijn afhankelijk van ontwikkelingen in innovaties en brandstofprijzen. In Figuur 4 is uitgewerkt wat zowel de bovengrens (42\% reductie) als de ondergrens (49\% reductie) zouden betekenen voor het mogelijke emissievolume in 2050 .

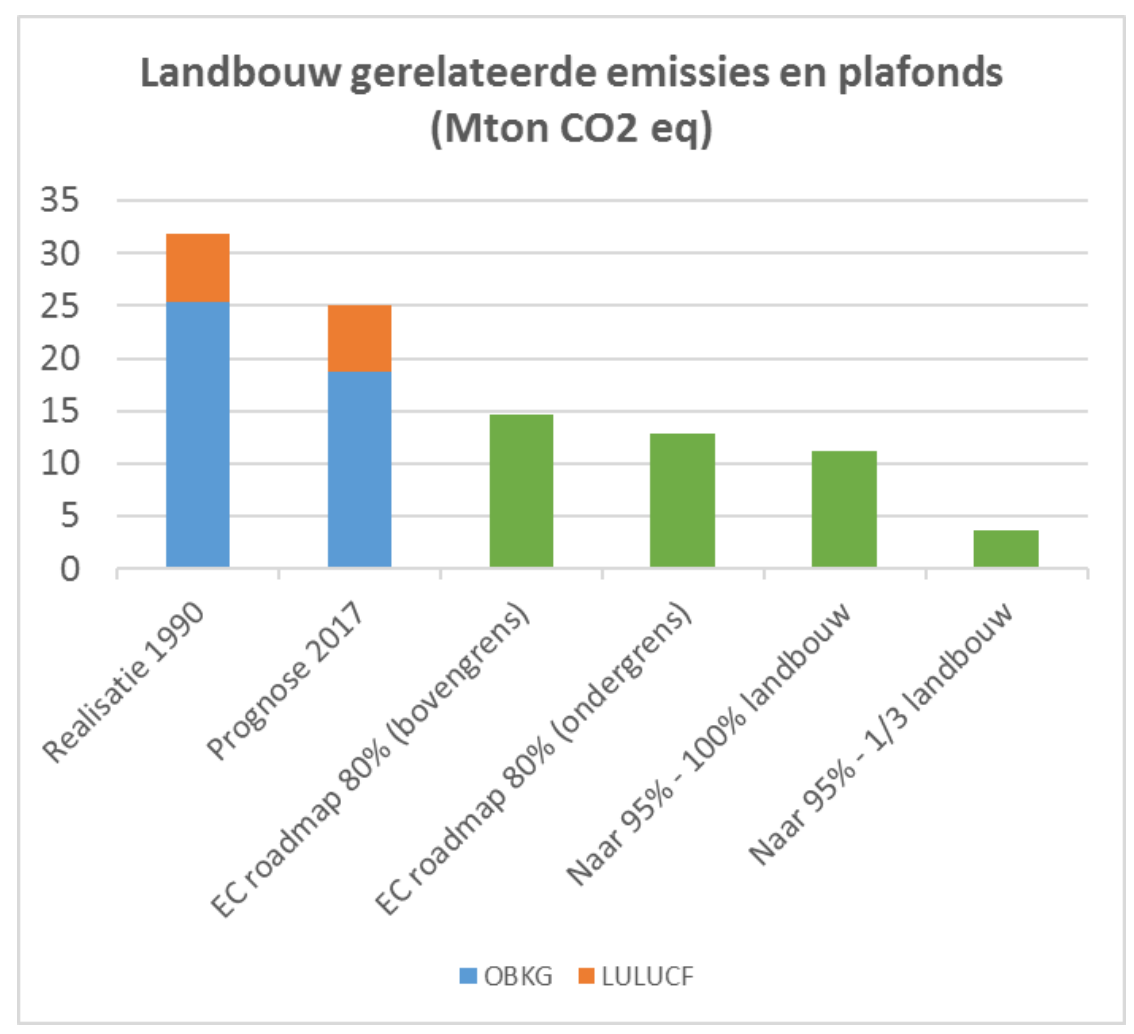

Figuur 4 De broeikasgasemissies van landbouw en landgebruik berekend volgens de NIR in 1990 en 2017 en de toegestane emissieplafonds voor de landbouw volgens vier scenario's. 
Deze vier varianten zijn in Figuur 4 vergeleken met het emissievolume in 1990 en 2017 om een beeld te krijgen van de omvang van de opgave in verschillende scenario's.

Hoewel in alle sectoren van de Nederlandse landbouw een opgave ligt voor vermindering van de broeikasgassen, is deze het grootste in de veehouderij. Ongeveer 90 - $95 \%$ van de totale emissies volgens de NIR zijn afkomstig van de veehouderij. Binnen de veehouderij is de melkveehouderij veruit de grootste sector vanwege het grote aandeel van methaan uit pensfermentatie. Zoals in het eerste hoofdstuk al is aangegeven, gaan we in de hier uitgevoerde berekeningen uit van de huidige grootte van de sectoren. Dat is niet omdat deze niet ter discussie mag staan, maar om een vergelijking te kunnen maken ten opzichte van de huidige situatie. Het geeft zo meer inzicht in de mate van reductie die mogelijk is met de huidige landbouwstructuur.

\subsection{Mitigatiestrategieën richting 2050: meer dan efficiëntieverbetering}

Er zijn verschillende manieren om emissie van broeikasgassen te beperken (ook wel mitigeren genoemd). Een rapport van de Vries et al. (2018, in voorbereiding) geeft een overzicht van groepen van mitigatiestrategieën. Dat staat beschreven in Tabel 2.

Tabel 2 Overzicht van mitigatiestrategieën voor landbouwproductie. Bron: de Vries et al. (2018, in voorbereiding).

\begin{tabular}{|c|c|}
\hline Mitigatietype & Voorbeeld \\
\hline 1. Efficiëntie verbeteren & $\begin{array}{l}\text { Melkproductie, levensduur, optimaliseren rantsoen, } \\
\text { precisiebemesting }\end{array}$ \\
\hline $\begin{array}{l}\text { 2. Aangrijpen op emissiebronnen } \\
\text { (biologisch/fysisch) }\end{array}$ & $\begin{array}{l}\text { Additieven voor remmen van methaan en lachgasvorming, } \\
\text { hernieuwbare energie, stalsystemen }\end{array}$ \\
\hline 3. End-of-pipe oplossingen & Mestgassen afvangen \\
\hline $\begin{array}{l}\text { 4. Structurele maatregelen } \\
\text { (A. binnen huidige systeem) }\end{array}$ & Grond uit gebruik nemen (veen) \\
\hline $\begin{array}{l}\text { 4. Structurele maatregelen } \\
\text { (B. buiten huidige systeem) }\end{array}$ & $\begin{array}{l}\text { Aquacultuur, synthetische vlees- en melkproductie, verandering } \\
\text { consumptiepatroon }\end{array}$ \\
\hline
\end{tabular}

De Nederlandse veehouderij kent reeds een lange traditie van efficiëntieverbetering en daarmee gepaard gaande emissiereductie (zie bijlage 4). De reductie van broeikasgassen loopt deels gelijk op met milieudoelen voor stikstof en fosfaat ( $\mathrm{N}$ en $\mathrm{P}$ ) en met de melkquotering. De melkquotering die gold tot 2015 heeft ertoe geleid dat het nationale quotum van ongeveer 11 Megaton met steeds minder koeien werd "volgemolken", waardoor de emissie van methaan van pensfermentatie en mest daalde (Vellinga et al., 2011). Door de stijging van de melkproductie is de voederconversie van melkvee verbeterd.

De mestwetgeving is steeds gericht geweest op de verbetering van de benutting van met name $\mathrm{N}$ in mest en voer en op de bijbehorende reductie van de uitstoot van ammoniak (Doornewaard et al., 2017) en in latere instantie ook op de betere benutting van P. Door de lagere ammoniakemissie en de lagere bemesting met kunstmest is de emissie van lachgas afgenomen in de melkvee-, varkens als de pluimveehouderij in de periode 1995 - 2010 (Kuling en Blonk, 2016; Coenen et al., 2018).

De mestwetgeving heeft zijn doorwerking gehad in zowel de melkveehouderij, als in de houderij van varkens, pluimvee en vleeskalveren. De efficiëntie van de houderij is sterk toegenomen, zowel wat betreft de omzetting van voer in producten (de z.g. voederconversie, zie bijvoorbeeld www.agrovision. nl voor varkens, en Kuling en Blonk, 2016), als wat betreft de benutting van $\mathrm{N}$ en de daarop volgende reductie van de excretie van N (Doornewaard et al., 2018). 
Het streven naar efficiëntie is in feite een vergaande optimalisering van de bedrijfsvoering met betrekking tot de productiviteit van dieren en loopt tegen een aantal grenzen aan:

- $\quad$ een veehouderijsysteem wordt kwetsbaarder, want alles moet precies passen, er is sprake van een steeds verdergaande conditionering van de dieren, het rantsoen en de overige bedrijfsomstandigheden. Dat vereist intensieve (bij)sturing.

- $\quad$ in de veehouderij kan deze ontwikkeling van optimalisatie op gespannen voet staan met de maatschappelijk gewenste ontwikkeling als beheerder van het landschap, natuurlijkheid van de productie en dierenwelzijn. De vervanging van de snelgroeiende vleeskuikens door trager groeiende dieren is hiervan een voorbeeld.

- $\quad$ minder efficiënte (oude) veerassen in termen van productie dreigen te verdwijnen, waardoor hun genetisch potentieel dat waarde kan hebben in andersoortige landbouwsystemen definitief verloren gaat.

- De nota "grondgebondenheid" in de melkveehouderij (NZO, 2018) sluit aan op de maatschappelijk gewenste ontwikkeling en op de wens om gras als basis voor de koe te houden en te versterken.

- De optimalisering kan ook leiden tot keuzes in veevoergrondstoffen die vanuit andere duurzaamheidsoogpunten minder gewenst zijn. De rol van veehouderij als verwerker van rest- en bijproducten neemt af. Er is een stijgende tendens naar het meer gebruiken van primaire producten. In de melkveehouderij wordt in toenemende mate gebruik gemaakt van pensbestendige producten die pas op dunne darm niveau worden verteerd. Deze producten vergen vaak een extra behandeling.

- $\quad$ in de melkveehouderij heeft een eenzijdige optimalisatie op melkproductie zijn afwenteling naar de vleesproductie, waardoor de in de zuivelsector behaalde reductie bij de productie van rundvlees wordt teniet gedaan.

- Ook in het traject van optimalisering is sprake van afnemende meeropbrengsten: er zijn steeds grotere inspanningen nodig om verbetering te bereiken. In Nederland is de toename van de melkproductie in de afgelopen 20 jaar gerealiseerd met een gelijkblijvend rantsoen (NEMA, 2018), waardoor dit effect nog niet zo sterk is. Het is onzeker of dit effect in de toekomst zal afvlakken of niet (De Vries et al., 2018).

- In de afgelopen jaren is de weidegang sterk verminderd, zowel in aantallen dieren, als in aantallen uren. Het convenant Weidegang heeft als doel de weidegang te stabiliseren. Een toenemende melkproductie per koe en de wens om de fosfaatexcretie te minimaliseren, zal op gespannen voet komen met weidegang.

- In de toekomst zal door klimaatverandering de adaptatie een belangrijk element worden en zullen robuuste bedrijfssystemen belangrijker worden. Emissiestrategieën die gericht zijn op vergaande optimalisering, zullen waarschijnlijk minder robuust zijn.

Hoewel de efficiëntie-strategie succesvol is gebleken in de afgelopen jaren, verwachten we dat de reductie die daarmee bereikt kan worden niet genoeg is om de gestelde doelen te bereiken. We denken dat een andere strategie ingezet moet worden om verdergaande emissiereducties te bereiken. Dat wil niet zeggen dat efficiëntieverbetering niet meer kan of mag worden toegepast, maar dat het geen onderdeel is van de uitgevoerde verkenning.

\subsection{Ingrijpen op emissiebronnen als basis voor toekomstige reductiestrategie}

In het voorgaande is geschetst wat de toekomstige ontwikkelingen zijn bij de technische verbetering op veehouderijbedrijven, met name in de voederconversie en het gebruik en productie van energie. De mate van verdere verbetering van de voederconversie hangt sterk af van ontwikkelingen in de sector in relatie tot de productiewijze. Juist die productiewijze staat in toenemende mate ter discussie, vanwege de effecten op dierenwelzijn en de beleving van de consument wat betreft de natuurlijkheid van dierlijke productie.

$\mathrm{Er}$ is in het vervolg van deze analyse gekozen om een verdergaande optimalisering van de efficiëntie niet centraal te zetten omdat het impliciet uitgaat van een zekere systeemkeuze in de huidige veehouderij: optimalisering op het hoofdproduct. De keuze van de maatregelen sluit aan bij de 
benadering die al is gebruikt door Kuling en Blonk (2016) en betreft het sturen op de belangrijkste bronnen van emissies: a) de vorming van methaan in de pens; b) de vorming van methaan en lachgas in de stal en bij de mestopslag; c) de vorming van lachgas bij aanwending en de toepassing van mest en kunstmest bij de teelt van gewassen; en d) de vastlegging van $\mathrm{C}$ in de bodem en het voorkomen van C-emissies uit veengronden.

De brongerichte benadering laat ruimte voor verschillende productiesystemen, zowel voor natuurinclusieve landbouw als een technisch geoptimaliseerde landbouw en mogelijke tussenvormen. Ook vergt de brongerichte benadering minder van het management van de veehouder en laat deze strategie ruimte voor klimaatadaptatie.

Bij de toepassing van deze brongerichte benadering is nog geen rekening gehouden met de maatschappelijke acceptatie, de kosteneffectiviteit, het benodigde onderzoek, de mate van stuurbaarheid en van implementatie en met de meetbaarheid van de emissiereducties. Een aantal van deze implementatievragen worden apart behandeld in een volgend hoofdstuk.

Mestverbranding is niet als maatregel meegenomen vanuit het uitgangspunt van volledig hergebruik van mineralen uit de mest als meststof, binnen dan wel buiten Nederland.

\subsubsection{Vermindering van methaan uit de pens}

Vermindering van methaan uit pens- en darmfermentatie van rundvee kan op een aantal manieren, welke hieronder per cluster worden behandeld:

\section{Voeding en additieven}

- Sebek et al. (2016) geven aan dat met voermaatregelen reducties tot $25 \%$ bereikt kunnen worden. Het gaat om het voeren van meer mais, van jonger gras en het toevoegen van vet aan het rantsoen.

- Hoewel het voeren van jong gras leidt tot minder methaan uit de pens, is het niet aan te raden. De winst van een lagere methaanproductie gaat verloren via extra lachgasemissies en machinegebruik per kg voer en via lagere grasopbrengsten. Deze maatregel is daarom niet meegenomen in de analyse.

- Mais is om meerdere redenen prima voer, het heeft een laag eiwitgehalte en heeft een lage methaanproductie. Maar uitbreiding van de teelt leidt tot landgebruiksverandering met verlies van organische stof uit de bodem. De derogatie legt beperkingen op aan de teelt van mais, hoewel op bedrijven met een hoge veebezetting nog steeds relatief meer mais gevoerd kan worden, vanwege de aankoop ervan. Deze maatregel is niet meegenomen in de analyse.

- De toevoeging van zetmeel aan het rantsoen kan ook zorgen voor lagere methaanemissies. Het dient dan als vervanger van andere energiebronnen gebruikt te worden. Als een mengvoer $10 \%$ zetmeel bevat, kan de methaanemissie met $0.2 \mathrm{~kg}$ methaan per $\mathrm{kg}$ voer worden gereduceerd, wat neerkomt op een daling van $1 \%$.

- Vet, het is nog wel zoeken naar het goede vet/olie om melksamenstelling niet te beïnvloeden. Per procent vet kan de methaanproductie met 4-5\% worden gereduceerd. Er kan echter niet te veel vet worden gevoerd. Bij $2 \%$ vet in het rantsoen is er 8 tot $10 \%$ reductie in de methaanproductie. Het effect van het gebruik van zetmeel en vet in het rantsoen is gecombineerd met andere maatregelen in deze paragraaf tot één totale reductie.

- Naast vet zijn er twee toevoegmiddelen bekend waarmee methaanemissie kan worden gereduceerd: 3NOP en nitraat. Deze werken additief aan vet, omdat ze alle drie aangrijpen op verschillende processen in de pens. Het methaanreductiepotentieel van 3NOP bedraagt 25$30 \%$, toevoeging van nitraat geeft reducties van $15 \%$.

- Zeewier wordt ook genoemd als een toevoegmiddel. In de literatuur zijn er enkele bronnen te vinden die hoge verwachtingen scheppen. Er is echter nog veel onduidelijk. Het gaat om specifieke zeewieren met hoge gehalten aan bromide. Het lot van bromide is onbekend, er is nog weinig in vivo-onderzoek gedaan. Daarnaast grijpt het aan op hetzelfde proces als 3NOP, dus is er eerder sprake van vervanging dan van aanvulling. Deze maatregel is daarom niet meegenomen in de analyse.

- Verder onderzoek naar individuele verschillen tussen dieren in de respons op toevoegmiddelen wordt gestart. 


\section{Fokkerij}

- $\quad$ Fokkerij op verhoging van de melkproductie is nog steeds mogelijk. In feite wordt de voeropname capaciteit van de dieren verder verhoogd, de voerefficiëntie verandert weinig. Deze maatregel is daarom niet meegenomen in de analyse.

- Selectie van dieren met een lagere methaanemissie per $\mathrm{kg}$ opgenomen voer is een perspectiefvol spoor. De inschatting is dat een reductie van $1 \%$ ten opzichte van het voorgaande jaar haalbaar is voor een zekere periode (pers. med. Y. de Haas). Voor de berekeningen zijn we uitgegaan van een toepassing van 30 jaren, dan kan een reductie van $24 \%$ worden bereikt.

- Additieven zijn nog steeds effectief in de situatie met een erfelijk verlaagde methaanvorming.

De reductie via fokkerij en additieven zullen elkaar aanvullen. Een combinatie van alle effecten komt uit op $(100-24 \%) *(100-50 \%)=38 \%$ van de oorspronkelijke emissies, een reductie van $62 \%$. In de berekeningen wordt uitgegaan van een reductie in methaanproductie van $50 \%$ als gevolg van de combinatie van fokkerij en additieven.

In de varkenshouderij is er nog de darmfermentatie die methaanemissies veroorzaakt. Deze emissie is gerelateerd aan de hoeveelheid vezels in het voer. Er wordt uitgegaan van een mogelijke reductie van $25 \%$.

\subsubsection{Vermindering van methaan en lachgas uit stal en mestopslag}

De vermindering van methaan en lachgas uit stal en mestopslag vergt een aanpassing van de stallen en de mestopslagen:

- Voor varkens en rundvee: stallen met gesloten vloeren, waarbij mest en gier met relatief hoge frequentie gescheiden wordt verzameld. Voor varkens kunnen verdergaande maatregelen worden getroffen dan voor rundvee (het varkenstoilet).

- Gescheiden en volledig afgesloten opslagen van mest en gier.

- Afvangen en verwerken van vrijkomende gassen uit de afgesloten opslagen. Dat kan via onder meer methaanoxidatie, affakkelen en andere methoden.

- Voor pluimvee: een snelle afvoer van de mest, gevolgd door een snelle droging.

Bijkomend voordeel van deze maatregelen is dat ze ook leiden tot een forse reductie van de emissie van ammoniak en tot het beschikbaar komen van vaste mest en gier als dierlijke meststoffen. Gedroogde pluimveemest wordt volledig ingezet als dierlijke meststof en niet meer verbrand. Theoretisch is een reductie van $100 \%$ mogelijk. In praktijksituaties zal dit percentage lager zijn. Voor zowel methaan als lachgas uit mestopslag is in deze analyse een reductiepercentage van $75 \%$ aangehouden.

\subsubsection{Vermindering van lachgas bij de aanwending van mest en kunstmest}

Vermindering van de lachgasemissies bij de aanwending kan plaatsvinden op de volgende manieren:

- Inzet van nitrificatie remmers. Er zijn nieuwe producten in ontwikkeling, onderzoek naar residuen loopt. De reductie van lachgasemissie kan 40 - 60\% van het huidige niveau bedragen.

- De grootschalige inzet van vlinderbloemigen in tijdelijk grasland, maar ook in blijvend grasland. Door minder kunstmest en de toepassing van nitrificatieremmers kan de lachgasemissie als gevolg van kunstmestaanwending met $75 \%$ dalen.

- $\quad$ Genetische vooruitgang in de plantaardige productie kan worden gebruikt om met minder inputs dezelfde opbrengst te bereiken. In de afgelopen decennia is een genetische voortuitgang geboekt van 0.5 - 1\% per jaar voor gewassen waar substantiële inzet gepleegd wordt op veredeling. Deze voortuitgang wordt nu niet meegerekend.

- De inzet van andere kunstmestsoorten en beslissingsondersteunende programma's en weersvoorspellingen om de lachgasemissie onder ongunstige omstandigheden te verminderen. Daarmee kunnen emissies gereduceerd worden in de orde van $10 \%$.

- Op veengronden zal door de maatregelen zoals peilverhoging en onderwaterdrainage de oxidatie van veen kunnen halveren. Daardoor neemt ook de mineralisatie van $\mathrm{N}$ af en daarmee het risico op de vorming van lachgas. Daartegenover staat dat door de nattere omstandigheden ook vaker anaerobe situaties kunnen optreden in de bodem, wat lachgasvorming kan stimuleren. Er is daarom gerekend met een beperkte afname van $25 \%$. 
- Door gebruik van de in de voorgaande paragraaf genoemde maatregelen zal ook de emissie van ammoniak en de uitspoeling van nitraat afnemen, waardoor ook de indirecte emissies van lachgas zullen afnemen, deze afname is nu geschat op $40 \%$.

De totale reductie van genoemde maatregelen komt op de lange termijn uit op $44 \%$ van alle lachgasemissie.

\subsubsection{C-vastlegging en emissies in en uit de bodem}

\section{Veengronden}

In veengronden gaat het om het tegengaan van de afbraak van organische stof, vastlegging is onder landbouwkundige omstandigheden niet mogelijk. Deze afbraak is een gevolg van ontwatering. Hoe dieper de ontwatering (het slootpeil ten opzichte van het maaiveld), hoe sneller de afbraak van organische stof gaat. De belangrijkste maat om de emissies te meten is de daling van het maaiveld. Bij slootpeilen van -60 en $-150 \mathrm{~cm}$ (de laatste zijn vindbaar in Friesland) is de daling 13 tot $25 \mathrm{~mm}$ per jaar. Eén millimeter maaiveldsdaling komt overeen met 2.26 ton $\mathrm{CO}_{2}$ per hectare.

Er zijn verschillende maatregelen om de afbraak van organische stof op veengrond te remmen of zelfs te stoppen:

- Onderwaterdrainage, waardoor binnen het perceel de grondwaterstand hoger blijft. Deze maatregel reduceert de afbraak van veen met 50\% (Van den Akker en Hendriks, 2014). Deze maatregel is effectief op percelen met een slootpeil van $60 \mathrm{~cm}$ beneden maaiveld.

- Peilverhoging voor de sterkst ontwaterde veengronden. Als de Gemiddelde Laagste Grondwaterstand (GLG) met $10 \mathrm{~cm}$ wordt verhoogd, vermindert de daling van het maaiveld met $2.35 \mathrm{~mm}$ per jaar. Dat komt overeen met ruim 5 ton $\mathrm{CO}_{2}$ per hectare. Met name de veengronden in Friesland kennen een sterke ontwatering met slootpeilen van $90 \mathrm{~cm}$ beneden het maaiveld en dieper. Bij verdergaande peilverhoging heeft deze maatregel grote gevolgen voor de bruikbaarheid van het land en de rendabiliteit van melkveebedrijven.

- Het realistische reductiepotentieel van peilverhoging en onderwaterdrainage wordt samen ingeschat op een hoeveelheid van 1,5 Megaton voor 2050, gebaseerd op de PBL (2016).

- Op termijn het uit productie nemen van veengronden. De slootpeilen worden dan dusdanig verhoogd dat de afbraak van veen wordt gestopt. Landbouwkundig gebruik in de huidige vorm is dan niet meer mogelijk, alternatieven zijn dan paludicultuur (natte landbouw) of omvorming naar natuur. In de berekening voor 2050 zijn we uitgegaan van 25000 ha die uit productie wordt genomen, dit is ruwweg $10 \%$ van het huidige veenareaal, en de bijbehorende emissiereductie is 0,5 Megaton.

\section{Minerale gronden}

Voor de minerale gronden (zand en klei) zijn de acties vooral gericht op het verhogen van het organische stofgehalte van zowel grasland als bouwland. Dat kan op grasland worden bereikt door:

- Niet scheuren van blijvend grasland voor een tussenteelt van een voedergewas of ander gewas voor een periode van één of twee jaar.

- Herinzaai van grasland (gras na gras) zoveel mogelijk beperken en vervangen door doorzaai van gras.

- Tijdelijk grasland voor een periode van maximaal drie jaar in afwisseling met bouwland (voedergewassen of anders) om de uitspoeling van stikstof naar grond- en oppervlaktewater te voorkomen.

- Beweiding van grasland wordt in sommige studies genoemd. De weiderest zorgt voor een grotere aanvoer van organische stof dan het verlies bij een maaisnede, maar de effecten op het gehalte aan organische stof zijn niet duidelijk.

- De aanvoer van organische stof op peil houden. Dit is bij grasland minder kritisch dan bij bouwland. Er is vaak al sprake van een hoge aanvoer uit stoppel, wortel en gewasresten. Tegelijk is de hoge stikstoflevering van blijvend grasland (100 - $150 \mathrm{~kg} \mathrm{~N}$ per ha per jaar) afkomstig uit de afbraak van aanwezige organische stof. Er komt veel organische stof bij, maar er gaat dus ook veel weer weg. Over het algemeen is de balans (licht) positief, zolang er niet wordt gescheurd. 
De aanvoer van organische stof op bouwland is belangrijker dan op grasland. Er is vaak sprake van lagere aanvoeren en door grondbewerking wordt de afbraak gestimuleerd. Voor bouwland zijn er de volgende mogelijkheden:

- De teelt van gewassen die meer stoppel, wortel en gewasresten achterlaten, zoals granen.

- De teelt van een groenbemester. Dit is uit meer oogpunten van belang. Nog beschikbare stikstof wordt opgenomen en er kan een substantiële hoeveelheid organische stof worden geproduceerd, zonder verdere aanvoer van nutriënten.

- Niet-kerende grondbewerking kan de afbraak van organische stof beperken. Voor rooigewassen zoals aardappelen, bieten, uien, peen en witlof vindt ook bij de oogst al een grondbewerking plaats. Bij de teelt in ruggen, zoals voor aardappelen, peen en witlof is niet kerende grondbewerking erg lastig. Het wordt in Nederland nog weinig toegepast.

- De aanvoer van organische stof via mest. Deze hoeveelheid wordt beperkt door de grenzen die zijn gesteld aan de aanvoer van $\mathrm{N}$ en $\mathrm{P}$ via de gebruiksnormen.

- De aanvoer van organische stof via compost.

- $\quad$ Bij de laatste twee is er altijd sprake van concurrentie met andere grondgebruikers. Mest en compost kunnen maar op één plaats worden aangewend. Als het naar de akkerbouw gaat, kan het elders niet meer worden gebruikt.

Vruchtwisseling: De afwisseling van grasland en bouwland in een vruchtwisseling heeft, mits goed uitgevoerd, voordelen voor de organische stofvoorziening van het bouwland, maar leidt tot een lager organisch stof gehalte op grasland. Tegelijkertijd zorgt iedere omzetting voor enige verliezen. Het risico van stikstofverliezen neemt toe. Enerzijds omdat vaak geen rekening wordt gehouden met de nalevering uit de gescheurde zode, anderzijds omdat de teelt van een groenbemester niet altijd succesvol is. Tegelijk is er een overdracht van stikstof van melkveehouderij naar akkerbouw. Als een dergelijke vruchtwisseling in balans is, zal het organische stof gehalte ongeveer gelijk zijn aan het gemiddelde van blijvend grasland en blijvend bouwland.

Hoewel de vastlegging van koolstof in organische stof een eindig proces is, is de verwachting dat tot 2050 door toepassing van nieuwe methoden deze vastlegging nog kan worden voortgezet. Op basis van Lesschen et al. (2012) is het realistisch potentieel voor vastlegging van het totaal van bovengenoemde maatregelen ingeschat op 1 Megaton $\mathrm{CO}_{2}$ per jaar.

\section{Verandering van landgebruik}

Wat betreft verandering van landgebruik kan worden gedacht aan het toepassen van agroforestry en het aanplanten van bos. Daarnaast kan ook worden gedacht aan de grootschalige toepassing en herstel van landschapselementen.

- $\quad$ Agroforestry is de combinatie van boomteelt met landbouw en veehouderij, deze biedt kansen op het gebied van milieu- en klimaatvriendelijke landbouw. Op dit moment is dit vooral een vorm van landbouw die in de tropen plaatsvindt en in Nederland nog alleen in eerste pilots wordt toegepast.

- $\quad$ Cijfers voor de potentie zijn daarom ook nog niet beschikbaar. Gebaseerd op IPCCrekenregels voor boomgaarden kan wel een eerste inschatting gemaakt worden. Uitgaande van een gemiddelde vastlegging van 1 ton C/ha/jaar en bij een areaal van 50000 in 2050 zal dit uitkomen op 0,2 Megaton $\mathrm{CO}_{2} /$ jaar.

- Voor bosaanplant is gerekend met een gemiddelde vastlegging van 3.3 ton $\mathrm{C} / \mathrm{ha} / \mathrm{jaar}$, dat is 12 ton $\mathrm{CO}_{2} / \mathrm{ha} / \mathrm{jaar}$

- Er zijn geen keuzen gemaakt waar deze bosaanplant moet of kan plaatsvinden, maar bij de aanname van 50000 ha bosaanplant is de jaarlijkse vastlegging 0.6 Megaton $\mathrm{CO}_{2}$.

De totale vastlegging per jaar kan 3.2 Megaton $\mathrm{CO}_{2}$ equivalenten per jaar bedragen, hetgeen neerkomt op $60 \%$ van de totale aan landbouw gerelateerde LULUCF-emissie. Daarvan komt 1 Megaton uit verbeterd landgebruik op minerale grond, 1.5 Megaton uit de verminderde emissie van veengrond en 0.7 Megaton uit agroforestry. 


\subsubsection{Glastuinbouw}

De sector glastuinbouw is anders dan de open teelten en de veehouderij. Tussen de Nederlandse glastuinbouw en de Nederlandse overheid is in 2014 de Meerjarenafspraak Energietransitie Glastuinbouw 2014-2020 gemaakt. In deze Meerjarenafspraak staat de totale $\mathrm{CO}_{2}$-emissie centraal. In deze Meerjarenafspraak is onder andere beschreven dat de glastuinbouw in 2050 een volledig duurzame en economisch rendabele energievoorziening wil hebben. Deze ambitie betekent dat de glastuinbouw in 2050 geen $\mathrm{CO}_{2}$-emissie meer kent. Om het $\mathrm{CO}_{2}$ doel en de ambitie voor 2050 te bereiken werken glastuinbouw en rijksoverheid samen in het programma Kas als Energiebron (KaE). De actuele speerpunten van KaE zijn energiebesparing (reductie energievraag), duurzame energie en energiewinst in de regio. Binnen KaE wordt gewerkt aan het benoemen van innovatie opgaven. Deze worden in deze studie daarom verder buiten beschouwing gelaten.

\subsubsection{Verdergaande technologische maatregelen in plantaardige en dierlijke productie?}

In de mitigatieopties die tot nu toe zijn benoemd is er nog ruimte voor een breed palet aan bedrijfssystemen, van intensief tot extensief, meer of minder natuur inclusief, e.d. Om de meest vergaande situatie te kennen is een extra variant doorgerekend waarbij $100 \%$ van de emissies uit stallen en mestopslagen wordt afgevangen en verwerkt tot neutrale gassen en producten $\left(\mathrm{CO}_{2}, \mathrm{~N}_{2}\right.$ en $\mathrm{H}_{2} \mathrm{O}$ ). Bij deze variant wordt een afgesloten stal ontwikkeld voor alle dieren in Nederland, waarbij dieren het gehele jaar op stal staan.

In de plantaardige productie kunnen de bodem-gerelateerde emissies verder verminderd worden door een aanzienlijk deel van de teelt te laten plaatsvinden onder glas.

\subsection{Emissiereducties buiten het primaire bedrijf en van energie}

Buiten de berekende emissies van lachgas en methaan op het primaire landbouwbedrijf zijn in de gehele productieketen nog andere emissies en reducerende maatregelen relevant:

- Het energiegebruik op het landbouwbedrijf bij de oogst van veevoer, melken, huisvesting, e.d. In de landbouw worden hiertoe al stappen ondernomen via warmtewisselaars, zonnepanelen en windturbines. In de toekomst wordt alle energie geproduceerd uit hernieuwbare bronnen. De totale emissie van het energiegebruik in het eindbeeld is derhalve op nul gesteld voor 2050. In dit kader moet worden nagedacht over een alternatief voor diesel voor tractoren, via het principe van "Carbon Capture and Utilization" (http://s3platform.jrc.ec.europa.eu/carbon-capture-andutilization), de productie van synthetische diesel. Ook kan worden gedacht aan de ontwikkeling van een volledige nieuwe vorm van mechanisatie, die een integratie is van precisie apparatuur en lichtere kleine machines om ook het vraagstuk van bodemverdichting te kunnen oplossen. Een dergelijke richting is ook gesuggereerd in de verkennende studie van het TKI-bureau.

- Het energiegebruik in de aanvoerketen en in de verwerking. De productie van kunstmest vergt veel energie. De Nederlandse productie van kunstmest is wereldwijd de meest klimaatvriendelijke door het voorkomen van lachgasemissies en een efficiënt energiegebruik, maar nog steeds is het een energie-vergend proces. Daarnaast is de aanvoer van veevoergrondstoffen uit de EU en van daarbuiten een belangrijke post: de emissies van teelt, verwerking en transport worden niet gerekend tot de Nederlandse emissies, maar maken wel een substantieel deel uit van de ketengerelateerde emissies, met name in de varkens- en pluimveehouderij. Het energiegebruik kan in 2050 volledig afkomstig zijn van hernieuwbare bronnen en de totale emissie van het energiegebruik in het eindbeeld is derhalve op nul gesteld. Dat is een vergaande stap, omdat Nederland dat niet alleen kan regelen en men afhankelijk is van het slagen van de energietransitie wereldwijd.

- De keuze van andere veevoergrondstoffen kan ook de lachgasemissies van de teelt in het buitenland verminderen. Ook kan het invloed hebben op de methaanproductie bij de pensfermentatie. 
- Hoewel binnen Nederland veel bijproducten uit de voedingsmiddelen- en drankenindustrie al worden gebruikt in de veehouderij, kan de benutting van onder meer dierlijke restproducten en een aantal humane afvalstromen ( $\mathrm{gft}$-afval en swill) sterk worden verbeterd. Veel van deze producten zijn rijk aan eiwit. Deze producten worden nu vanwege voedselveiligheid niet meer ingezet als veevoer. Onder strikte voorwaarden is dat wel mogelijk. Een deel van de dierlijke restproducten wordt nu nog ingezet als energiebron bij de elektriciteitsproductie. Maar dat is op termijn ook niet meer aan de orde. 


\section{$4 \quad$ Emissiereducties in 2050}

\subsection{Reductie van bronemissies}

Op basis van de toepassing van reducties van bronemissies in het vorige hoofdstuk kan de totale emissie worden teruggedrongen met ruim 22 Megaton $\mathrm{CO}_{2}$ equivalenten in 2015. Volgens de ketenbenadering kan de reductie zelfs het dubbele zijn, 45 Megaton (Tabel 3).

Tabel 3 De potentiële reductie van broeikasgasemissies in 2050 voor de landbouw volgens de NIR (categorieën 1.1, 1.2 en 1.3) en de gehele keten (alle categorieën).

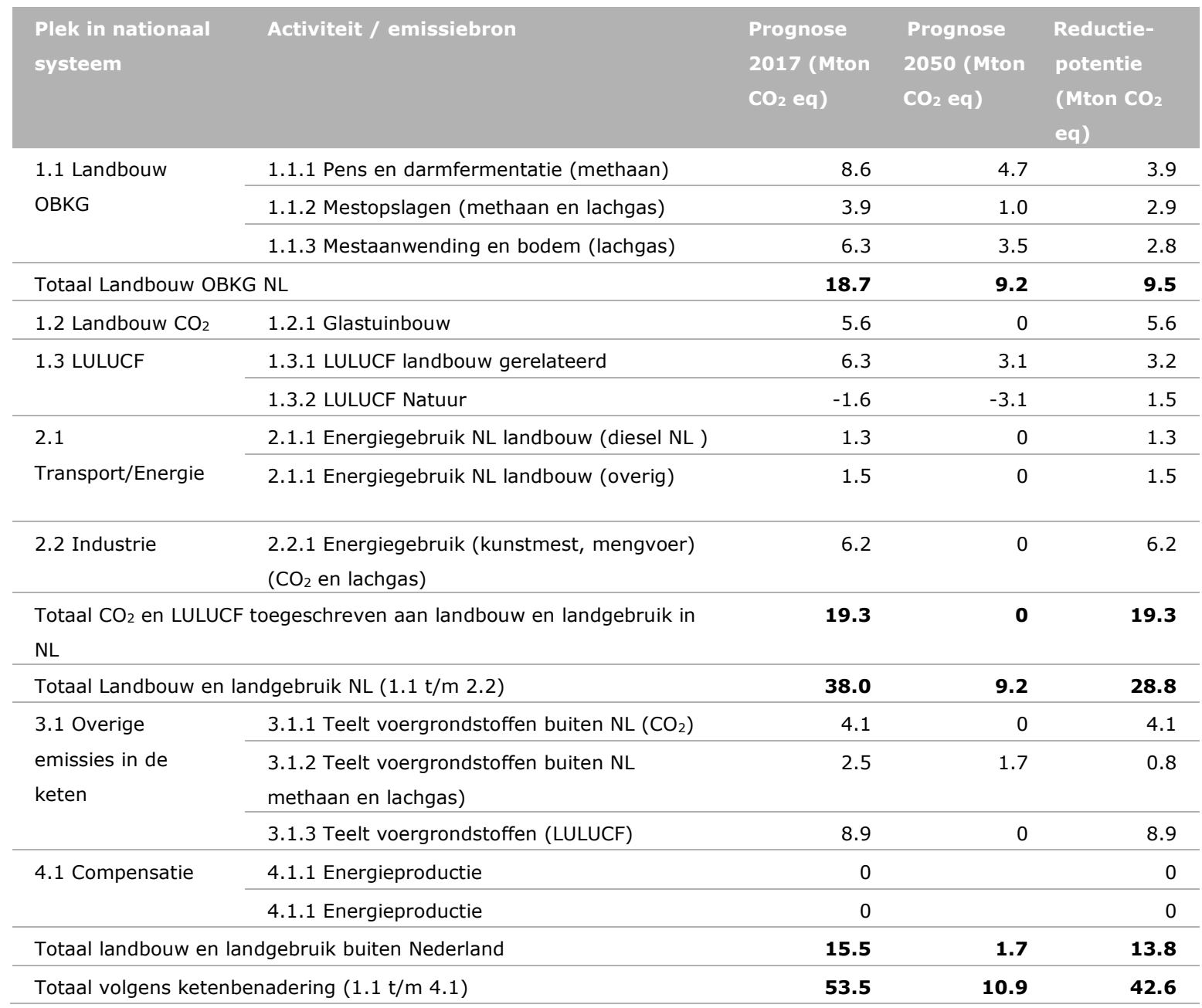

\subsection{De optie van $100 \%$ afgesloten stallen}

Als wordt gekozen voor volledig afgesloten stallen en opslagen en het jaarrond op stal houden van alle dieren, dus ook rundvee, kan de emissie van broeikasgassen op het primaire bedrijf (categorie 1.1) zelfs verder worden teruggedrongen tot minder dan 3 Megaton $\mathrm{CO}_{2}$ equivalenten. Zie Tabel 4. 
Tabel 4 De potentiële reductie van broeikasgasemissies in 2050 voor de landbouw volgens de NIR (categorieën 1.1, 1.2 en 1.3) bij toepassing van vergaande maatregelen met betrekking tot de constructie van stallen en het op stal houden van dieren.

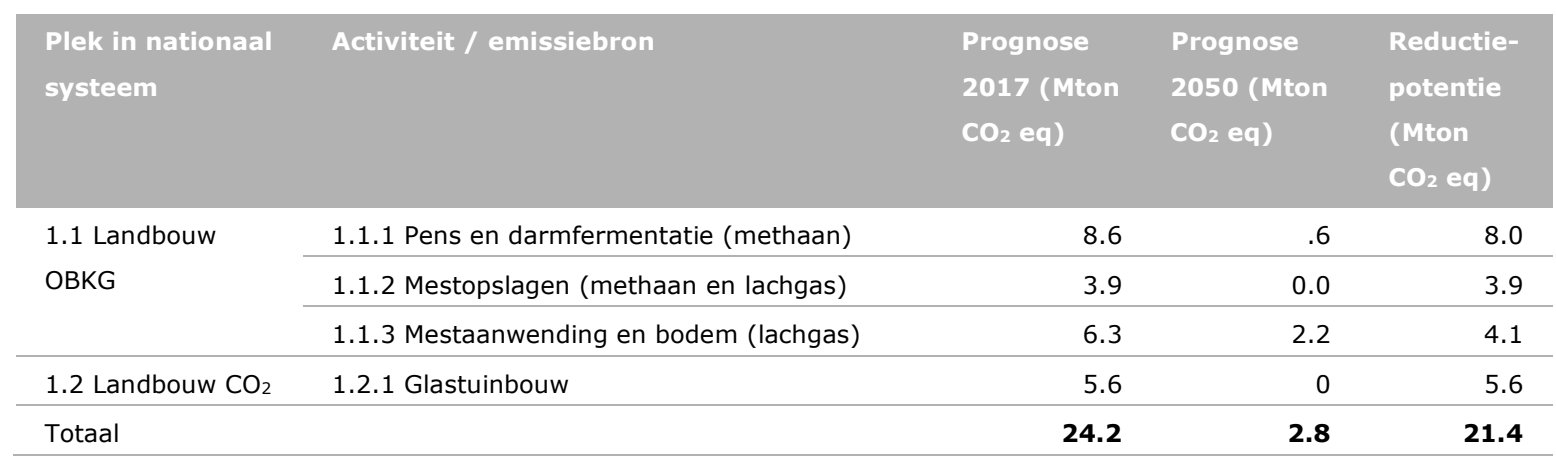

\subsection{Productie van energie als mitigatie en compensatie?}

De Nederlandse landbouw is een energie-intensief productiesysteem, dat geldt zeker voor de glastuinbouw, maar ook voor alle andere vormen van plantaardige en dierlijke productie. Een aanzienlijk deel van de energie wordt buiten het primaire bedrijf gebruikt, bij de productie van kunstmest en bij de teelt, verwerking en transport van extern aangekocht veevoer.

De Nederlandse agrosectoren kunnen bijdragen aan de vermindering van broeikasgasemissies door a) hun directe energiegebruik te vergroenen via energieproductie op het eigen bedrijf via zonnepanelen, windturbines of mestvergisting en $b$ ) landbouwbedrijven hebben de ruimte om bij te dragen aan energieproductie voor het indirecte energiegebruik in de gehele keten in Nederland en c) bij voldoende ruimte nog extra energie te produceren om bij te dragen aan de energievoorziening van Nederland als geheel.

Met betrekking tot $a$ en $b$ gaat het om een reductie van 9.03 Megaton $\mathrm{CO}_{2}$ equivalenten voor de overige landbouwsectoren (exclusief glastuinbouw), inclusief toeleverende bedrijven. Uitgaande van de inzet van zonneweides en windturbines geeft Tabel $\mathbf{5}$ een indicatie van de oppervlakte en aantallen die nodig zijn voor de compensatie van $\mathrm{CO}_{2}$.

Tabel 5 De compensatie van $\mathrm{CO}_{2}$-emissies met windturbines en zonneweides en de efficiëntie waarmee energie uit elektriciteit omgezet kan worden in groene brandstoffen.

\begin{tabular}{lr} 
Zonneweides (hectares) & Compensatie in Mton $\mathrm{CO}_{2}$ \\
\hline 1,000 & 0.2 \\
\hline 10,000 & 2.3 \\
\hline 100,000 & 23.0 \\
\hline Windturbines (vermogen in MW) & 0.1 \\
\hline 100 & 1.0 \\
\hline 1,000 & 10.0 \\
\hline 10,000 & \\
\hline Carbon Capture and Utilization & 0.5 \\
\hline
\end{tabular}

In de zonneweides is gerekend met $36 \%$ zonnecellen, zodat nog ruimte overblijft voor landschappelijke inpassing en mogelijke teelten (Spruijt en Terbijhe, 2016). Er wordt onderzoek gestart naar de mogelijkheid tot gewasteelt in combinatie met zonnepanelen (pers. med. A. Visser). Mobiele zonnepanelen worden genoemd als een mogelijkheid om de teelt van groenbemesters als rustjaren in een bouwplan te combineren met de plaatsing van panelen.

Het grootschalige gebruik van zonnepanelen zal een sterk beslag op de beschikbare ruimte leggen. 


\section{Implementatie van de maatregelen}

De maatregelen zijn eenvoudig op papier te zetten, maar een succesvolle invoering ervan is afhankelijk van een aantal factoren. Voor alle maatregelen is een inschatting gemaakt van:

- Het huidige niveau van de toepasbaarheid van de maatregel in de praktijk. Dat wordt uitgedrukt in de z.g. Technical Readiness Level (TRL), een gestandaardiseerd systeem van de Europese Commissie om de praktijkrijpheid van nieuwe vondsten te beoordelen (http://ec.europa.eu/research/participants/data/ref/h2020/wp/2014_2015/annexes/h2020wp1415-annex-g-trl_en.pdf).

- De maatschappelijke acceptatie van een maatregel. Het kan zijn dat er maatschappelijke weerstand is tegen een maatregel. Dat kan te maken hebben met een principe, zoals het streven naar een "natuurlijk" systeem, of met mogelijke risico's voor de volksgezondheid of biodiversiteit of met de perceptie van mensen.

- De kosten van invoering van de maatregel. Een maatregel kan geld opleveren, zoals vaak het geval was bij de maatregelen die de efficiëntie verbeterden. Maar nieuwe maatregelen zullen vaak geld kosten, omdat er geen extra opbrengst tegenover staat, maar wel kosten gemaakt moeten worden.

- De mate waarin systeemaanpassingen nodig zijn. Dat kan variëren van geen aanpassingen, kleine aanpassingen op het primaire bedrijf tot aanpassingen door de gehele keten.

De tabellen waarin bovenstaande aspecten per maatregel zijn uitgewerkt, staan in Bijlage 3.

Op basis van het overzicht van maatregelen zijn de volgende conclusies worden getrokken:

1. Er zijn al veel maatregelen met een hoge TRL. De toepassing van die maatregelen wordt vooral tegengehouden door hoge kosten, concurrentie om grond en maatschappelijke weerstand. Daarbij valt te denken aan het gebruik van toevoegmiddelen tegen methaan en lachgas, die geen extra opbrengsten genereren, maar wel kosten veroorzaken. Verhoging van waterpeilen in de veenweidegebieden en de toepassing van onderwaterdrainage worden al toegepast, maar brengen kosten met zich mee en stuiten daarom op weerstand. Tegelijkertijd kunnen deze middelen onderwerp zijn van maatschappelijk debat, zowel in negatieve als positieve zin. Verhoging van waterpeilen kan onderdeel zijn van een meer natuur gerichte landbouw. De introductie van maatregelen met een hoge TRL kan worden ondersteund met kennisverspreiding (vergelijkbaar met de grote kennisprogramma's over $\mathrm{N}$-benutting eind jaren 90 vorige eeuw), regels, regelingen e.d.

2. Een aantal maatregelen heeft een lage TRL:

a) De genetische mogelijkheden kunnen nog beter worden benut. Tot nu toe zijn deze in de dierlijke sectoren vooral ingezet op efficiëntie. Deze kunnen wat betreft herkauwers sterker worden gericht op lagere methaanemissies. Het z.g. proof-of-principle is bekend.

b) De toepassing van additieven voor remming van methaanemissie en lachgasvorming in de bodem. Er worden nieuwe middelen ontwikkeld. Een belangrijk aspect is hoe ingrepen in een schakel van de keten doorwerken op latere schakels. Om ingrepen beter te kunnen ontwerpen en begrijpen is het belangrijk om meer inzicht te krijgen in de C- en $\mathrm{N}$ dynamiek van biomassa, zowel wat betreft de productie van biomassa, de verwerking ervan tot producten, de vertering in mens en dier en uiteindelijk de verwerking van excrementen tot producten die weer aan het begin staan van een nieuwe cyclus.

3. Een tussenvorm wordt ingenomen door de z.g. nul-emissie stal, waarbij emissies van ammoniak, lachgas, methaan (en fijnstof) tot een minimum worden teruggebracht. Dat vereist een integrale aanpak van stal, mestopslag en latere verwerking van mest en gier.

4. De energietransitie: de landbouw is een productiesysteem dat zich kenmerkt door veel kleinere bedrijven (in vergelijking met andere productiesectoren, zoals auto-industrie). Dat vereist andere technologie. Tegelijkertijd is de landbouw het systeem dat biomassa produceert en dat ruimte heeft voor andere vormen van energieproductie. De wens om biomassa te gebruiken voor velerlei toepassingen en de plannen om ruimte te gebruiken voor zonneweiden zorgt voor een sterkere concurrentie om land dan tot nu toe. 


\section{De resultaten in een breder kader}

\subsection{De ruimte voor landbouw in Nederland.}

Of de emissie vanuit de landbouw na toepassing van bovenomschreven pakket van mitigatiemaatregelen past binnen de emissieruimte van Nederland, is sterk afhankelijk van de beleidsvariant die van toepassing is.

Bij drie van de vier uitgewerkte beleidsvarianten past de gemodelleerde emissie binnen het berekende plafond voor 2050. Als het meest vergaande scenario in 2050 van toepassing is ( $95 \%$ reductie in Nederland met één derde van de overgebleven ruimte als emissieruimte voor landbouw), moet de landbouwsector naar $40 \%$ van het huidige volume krimpen (Tabel 6), zelfs na volledige toepassing van alle emissie reducerende maatregelen zoals beschreven in de hoofdstukken 3 en 4. Gezien de grote bijdrage van de veehouderij aan de emissie is volume beperking in de veehouderij dan het meest effectief.

Tabel 6 Mogelijke productievolumes van de Nederlandse landbouw bij verschillende emissiescenario's voor 2050.

\begin{tabular}{lccc} 
Beleidsvariant & $\begin{array}{c}\text { Emissieruimte landbouw } \\
\text { (Mton) }\end{array}$ & $\begin{array}{c}\text { Mogelijk productievolume (\% van huidig) a.g.v. } \\
\text { emissieruimte }\end{array}$ \\
\hline Reductie $80 \%$ bovengrens & 14.7 & 100 \\
\hline Reductie $80 \%$ ondergrens & 12.9 & 100 & 100 \\
\hline Reductie 95\% 100\% landbouw & 11.2 & 40 \\
\hline Reductie 95\% 33\% landbouw & 3.7 & 4 \\
\hline
\end{tabular}

\subsection{De relatie tussen productie en consumptie in Nederland}

Een aanzienlijk deel van de dierlijke productie in Nederland wordt geëxporteerd, de binnenlandse consumptie is minder dan 50\% van het productievolume. In 2017 bedroeg de totale exportwaarde 29.1 miljard euro. De EU als geheel is veruit de belangrijkste afzetmarkt: $78 \%$ van de waarde wordt binnen de EU verhandeld. Duitsland, België, Frankrijk en het Verenigd Koninkrijk zijn belangrijke landen, met in totaal $54 \%$ van de totale uitvoer. Nederland fungeert als leverancier voor het sterk verstedelijkte Noordwest-Europa. De uitvoer naar buiten de EU betreft primaire producten, maar ook verwerkte producten die in Nederland zelf niet worden geconsumeerd, zoals kippenpoten en -vleugels, varkensoren e.d.

Wat betreft de akkerbouw is Nederland importerend voor zowel granen, oliezaden en overige veevoergrondstoffen. Bij de granen betreft dat zowel voor de baktarwes (menselijke consumptie) als de voergranen. Van de Nederlandse mengvoergrondstoffen is $40 \%$ van Nederlandse oorsprong, $35 \%$ komt uit de EU en $16 \%$ uit Latijns-Amerika. Voor aardappelen en suikerbieten is Nederland exporterend: ongeveer een derde van de Nederlandse productie is nodig voor binnenlandse consumptie, terwijl de rest wordt geëxporteerd, waarvan een aanzienlijk deel naar landen buiten de EU.

Wat de tuinbouw betreft wordt ongeveer $40 \%$ van de geteelde groenten voor binnenlandse consumptie aangewend. De Nederlandse export gaat vooral naar EU-landen (90\%).

De sterke verweving van de Nederlandse productie en consumptie met import en export, met name van en naar de Europese Unie is aanleiding tot de vraag of bij een mitigatiestrategie voor de landbouw de binnenlandse consumptie maatgevend moet zijn of dat Europa als oplossingsruimte gekozen moet worden. 


\subsection{Vraag naar biomassa en ruimte neemt toe: grond is schaars}

In Nederland en daarbuiten is een groeiende vraag naar land voor verschillende functies, waaronder voor cultuur (incl. bebouwing en infrastructuur), waterberging, productie van zonne-energie middels zonneweides, en voor de productie van biomassa. Biomassa kent vele toepassingen, waaronder voor de productie van voedsel, voer, hernieuwbare energie, en biobased toepassingen in chemie/farmacie en industrie. Verwachtingen van de productie en behoefte aan biomassa zijn geschat door Broeze en Elbersen (2017). De auteurs verwachten een lichte stijging van de biomassabehoefte voor voedsel, een constante behoefte voor veevoer en een sterk stijgende behoefte voor biobased producten. In de laatste categorie zijn ook biobrandstoffen meegerekend. De huidige behoefte aan biomassa wordt geschat op 41 Megaton, terwijl de behoefte oploopt naar 128 Megaton in 2050, waarvan 85 Megaton voor de productie van warmte, elektriciteit en transportbrandstoffen, 9 Megaton als grondstof voor de productie van materialen en 34 Megaton voor voeding van mens en dier. Als het meest vergaande scenario voor 2050 wordt gehanteerd, zal de biomassa behoefte voor voeding van mens en dier dalen naar ongeveer 17 Megaton. Hierboven op komt nog de extra vraag naar biomassa voor vastlegging van $\mathrm{C}$. Ten opzichte van de extra vraag naar biomassa in de energietransitie is deze extra vraag voor vastlegging in de bodem slechts beperkt. Voor de extra vastlegging van koolstof in landbouwgronden is in hoofdstuk 3 en 4 gerekend met 1 Megaton $\mathrm{CO}_{2}$ equivalenten per jaar. Daarvoor is ongeveer 0.3 Megaton $\mathrm{C}$ nodig. OM deze vastlegging op lange termijn te garanderen is de biomassabehoefte daarvoor ongeveer 3 Megaton per jaar.

Ter vergelijking: Broeze en Elbersen (2018) berekenen voor Nederland een huidige biomassa productie van 21 Megaton per jaar en schatten op basis van lange termijn verkenningen van de FAO dat deze kan groeien tot 24 Megaton in 2050. Er is dus een enorme kloof te overbruggen om aan de toenemende vraag te kunnen voldoen, zeker wanneer biomassa ook ingezet gaat worden voor de productie van energie.

Nederland is ook in de toekomst niet zelfvoorzienend voor biomassa met de huidige productie. De druk op de grond zal hoog blijven. Door klimaatverandering zal de productiviteit wereldwijd onder druk staan en kan leveringszekerheid een belangrijk vraagstuk worden. Een betere eigen biomassaproductie of een beter geoptimaliseerde biomassaproductie (volgens meerdere doelen), blijft ook dan een belangrijke vraag. In de mitigatiestrategie, zoals in voorgaande hoofdstukken is beschreven zijn al verschillende aanspraken op grond gemaakt:

- De agroforestry en extra bosaanplant, in totaal 100000 hectare;

- Het uit cultuur nemen van 25000 hectare veenweidegebieden, in combinatie met vernatting van de overige veengronden;

- Het ruimtebeslag voor de aanleg van zonneweides. Voor alleen compensatie van de energieemissies van de landbouw en glastuinbouw gaat het om tienduizenden hectares (uitgaande van 50/50 voor wind/zon). Daarnaast zijn er vele andere partijen die de grond willen gebruiken voor energieproductie. Als zonneweides een substantieel deel van de energieproductie voor zijn rekening moet nemen, zal het ruimtebeslag eerder geteld worden als honderdduizend hectare of meer.

De toenemende vraag zal dus druk leggen op het landgebruik, niet alleen binnen Nederland, maar ook zeker daarbuiten. Het is dus zowel een nationaal als een internationaal vraagstuk. Het gevecht om de ruimte leidt concreet tot drie grote vraagstukken: a) hoe zal de sturing van het ruimtegebruik binnen Nederland worden ingevuld; b) hoe gaat Nederland zijn "externe" biomassa regelen; en c) hoe worden de technische innovaties die nodig zijn om de groeiende vraag naar biomassa te dekken tot stand. Te denken valt dan andere teelten, maar ook aan verbetering van de productiviteit van planten en de winbaarheid van grondstoffen. Een grotere import van biomassa zal ook zeker zijn gevolgen hebben voor de accumulatie van mineralen in Nederland en de bijbehorende overschotten.

Uit de cijfers van de biomassabehoefte blijkt dat het gebruik van biomassa als grondstof voor energie de vraag zeer sterk doet toenemen. Het is de vraag of een dergelijke grote vraag beantwoord kan worden. Het inzetten op andere vormen van energieproductie dan biomassa zal in het energieonderzoek prioriteit moeten krijgen. 
De achteruitgang van de biodiversiteit krijgt toenemende aandacht (zie Deltaplan Biodiversiteitsherstel). Hoewel daar geen expliciete aanspraken op grond worden genoemd, is het waarschijnlijk dat meer aandacht voor biodiversiteit in de Nederlandse landbouw eerder een extensivering van de productie zal betekenen dan een verdergaande intensivering.

De omvang van de veestapel is uiteraard geen vast gegeven is in de toekomst. Verkleining van de veestapel (met name rundvee) is de meest snelle manier om emissievolumes te verminderen en kan grond vrijmaken voor andere vormen van gebruik. De behoefte aan plantaardige productie zal mogelijk toenemen als gevolg van veranderingen in consumptie en. Een verschuiving naar meer plantaardige productie kan een verschuiving van grasland naar bouwland betekenen wat op zijn beurt weer negatieve gevolgen kan hebben voor de vastlegging van koolstof in landbouwgronden en voor de biodiversiteit.

Deze mogelijke veranderingen in ruimtegebruik vergen twee vormen van innovatie:

1. Technische innovatievraagstukken, in het domein van biorefinery en van integratie van landgebruiksfuncties. Met integratie van landgebruiksfuncties kunnen bijvoorbeeld gewasteelt en productie van energie middels zonnepanelen zodanig worden geïntegreerd op een hectare dat de netto-opbrengst van het systeem groter is dan wanneer gewasteelt en productie van zonne-energie op gescheiden hectares zou plaatsvinden. Agroforestry is een systeem dat bekend is van de (sub)tropen en wat mogelijk perspectief kan bieden voor de vraag naar vastlegging van koolstof, de productie van biomassa en de rol bij het herstel van de biodiversiteit in Nederland. Biorefinery kan zich enerzijds richten op verdere optimalisatie van het splitsen van biomassa, maar mogelijk ook op een volledig synthetische productie en vergelijkbaar met Carbon Capture and Utilization gebruik maken van $\mathrm{CO}_{2}$.

2. Governance vraagstukken zijn van belang om de groeiende vraag naar bovengenoemde functies bestuurlijk en maatschappelijk in goede banen te leiden. Hoe sturen we een optimaal gebruik van biomassa op het niveau van de economie middels waard creatie? Hoe geven we een landschap vorm die voldoet aan de gewenste functies in een verstedelijkte omgeving en die tegelijkertijd maatschappelijk geaccepteerd wordt? Hoe voorkomen we dat de invulling van het ruimtegebruik in Nederland alleen een kwestie wordt van het recht van de economisch sterkste? Het is belangrijk om met elkaar speleregels te ontwikkelen waarin ook het publieke belang wordt meegewogen. 


\section{$7 \quad$ Conclusies}

Op basis van deze verkenning kunnen de volgende conclusies worden geformuleerd:

1. $\mathrm{Er}$ is op basis van de huidige kennis, inzichten en verwachtingen in wetenschappelijk onderzoek een forse potentie voor reductie van broeikasgasemissies uit de Nederlandse landbouw en landgebruik op de lange termijn.

2. Om deze reductie te bereiken is veel meer nodig dan het voortzetten van het efficiëntiespoor. De reductie kan worden gerealiseerd door aanpak van emissiebronnen zelf (methaan pens, mest, lachgasvorming) met steeds verder afnemend gebruik van end-of-pipe methoden (afvangen emissies mest).

3. Het reductiepotentieel in de gehele productieketen, met name de productie van veevoer en kunstmest, binnen en buiten Nederland is veel groter dan alleen in de primaire productie in Nederland.

4. Een aantal voorgestelde maatregelen zijn bijna praktijkrijp, de toepassing ervan wordt belemmerd door kosten, kennis, concurrentie om grond en maatschappelijke acceptatie. Een grootschalig introductieprogramma kan zorgen voor versnelling.

5. In de landbouw ligt een forse reductieopgave met betrekking tot energiegebruik maar deze valt niet binnen de NIR-landbouw. De uitdaging hoe deze energietransitie in de landbouw georganiseerd moet en kan worden en hoe deze inspanning van de landbouw zichtbaar wordt in emissierapportages.

6. De opgave van vermindering van emissies kan niet los worden gezien van vier grote transities waar de Nederlandse landbouw en voedselproductie mee te maken heeft: energie, eiwit, biobased economie en circulaire economie. Klimaat en de vier genoemde transities leiden samen tot een veranderende en waarschijnlijk groeiende vraag naar biomassa en land.

7. De grote opgaven voor de lange termijn liggen in

a. Transitie, governance en beleid: hoe komen tot een proces waarin een goede afweging kan plaatsvinden tussen economische en publieke belangen bij het sturen van veranderend landgebruik, productie van biomassa en een klimaatbestendig landschap

b. Techniek: Het ontwikkelen van innovaties waarmee productie van biomassa, een vergaande reductie van emissies van methaan en lachgas en voortgaande vastlegging van koolstof in landbouw- en natuurgronden in de praktijk mogelijk worden zonder negatieve gevolgen voor andere doelen. 


\section{Literatuur}

Broeze, J. en Elbersen, W. (2018). Peer review Nederlandse beschikbaarheid en vraag naar voedsel, veevoer en biomassa voor non-food in 2030 en 2050. Rapport Wageningen Food \& Biobased Research. In voorbereiding.

Centraal Bureau voor de Statistiek en Wageningen Economic Research (2018). De Nederlandse Landbouwexport 2017. Rapport CBS/WEcR, Den Haag 120 pp.

Coenen, P.W.H.G. van Zanten M.C., Zijlema P.J., Arets E.J.M.M., Baas K., van den Berghe A.C.W.M., van Huis E.P., Geilenkirchen G.,'t Hoen M., Hoogsteen M., te Molder R., Dröge R., Montfoort J.A., Peek C.J., Vonk J., Dellaert S., Koch W.W.R.. (2018) Greenhouse gas emissions in the Netherlands 1990-2016. National Inventory Report 2018. RIVM Report 2018-0006

De Vries, M., Vellinga, Th.V., Hoving, I., Van Middelkoop, J., Ten Napel, J., Verhagen, J, Van Der Weide R. (2018) Klimaatslimme melkveehouderij. Een routekaart voor implementatie van mitigatie- en adaptatiemaatregelen. Rapport WLR in voorbereiding.

Doornewaard G.J., J.W. Reijs, A.C.G. Beldman, J.H. Jager en M.W. Hoogeveen, 2017. Sectorrapportage Duurzame Zuivelketen; Prestaties 2016 in perspectief. Wageningen, Wageningen Economic Research, Rapport 2017-087. 200 blz.; 24 fig.; 11 tab.; 103 ref.

European Commission (2011). Low Carbon Roadmap, http://www.roadmap2050.eu.

Kramer, G. en Blonk H. (2015). Menu van morgen. Gezond en duurzaam eten in Nederland: nu en later. Rapport Blonk Consultants, Gouda, $65 \mathrm{pp}$.

Kuling, L. en Blonk, H. (2016) Trendanalyse broeikaseffect dierlijke producten. Rapport Blonk Consultants, Gouda, 33 pp.

Nevedi (2016) Wijzer over grondstoffen. https://www.nevedi.nl/vereniging/grondstoffenwijzer-nevedi2016.

Eerste Kamer (2011). https://www.eerstekamer.nl/eu/europeesvoorstel/com_2011_112_commissiemededeling/docume $\mathrm{nt} / \mathrm{f}=/$ vinnfzzzj7si.pdf

Raad voor de Leefomgeving en Infrastructuur (2018). Duurzaam en gezond. Samen naar een houdbaar voedselsysteem. Rapport RLI, 98 pp.

Šebek, L.B., Mosquera, J., Bannink, A. 2016. Rekenregels voor de enterische methaanemissie op het melkveebedrijf en reductie van de methaanemissie via mest-handling; het handelingsperspectief van het voerspoor inzichtelijk maken met de Kringloopwijzer. Lelystad, Wageningen UR (University \& Research centre) Livestock Research, Livestock Research Rapport 976.

Spruijt, J. en Terbijhe A. (2016) Perspectief zonnestroom in de agrarische sector. Rapport PPO 690, Wageningen/ACCRES, $35 \mathrm{pp}$.

Transitieagenda circulaire economie: Biomassa \& Voedsel.

Van den Akker, J. J. H. en Hendriks R. F. A., (2014). Veenweiden: aangepast watermanagement noodzakelijk voor beperking veenafbraak. Hogere grondwaterstanden voor veenweiden. Bodem, nummer 6, blz. 7-9.

Van der Velden N. en Smit, P. (2017) Energiemonitor glastuinbouw 2016. Wageningen Economic Research, rapport2017-094, 54 pp.Vonk, J., A. Bannink, C. van Bruggen, C.M. Groenestein, J.F.M. Huijsmans, J.W.H. van der Kolk, H.H. Luesink, S.V. Oude Voshaar, S.M. van der Sluis \& G.L. Velthof, 2018: Methodology for estimating emissions from agriculture in the Netherlands. Calculations of $\mathrm{CH}_{4}, \mathrm{NH}_{3}, \mathrm{~N}_{2} \mathrm{O}, \mathrm{NOx}, \mathrm{PM} 10, \mathrm{PM} 2.5$ and $\mathrm{CO}_{2}$ with the National Emission Model for Agriculture (NEMA). WOT-report 2018.53. WOT Nature and Environment, Wageningen. 


\section{Bijlage 1 Uitwerking reductie broeikasgasemissies van de Nederlandse landbouw per onderdeel}

\begin{tabular}{|c|c|c|c|c|}
\hline Breakdown OBKG NIR in Mton $\mathrm{CO}_{2}$ equivalenten & $\begin{array}{l}\text { Prognose } \\
2017\end{array}$ & $\begin{array}{l}\text { potentieel } \\
\text { reductie } \% \\
2050\end{array}$ & $\begin{array}{l}\text { Haalb } \\
\text { aar in } \\
2050\end{array}$ & Omschrijving maatregelen \\
\hline \multicolumn{5}{|l|}{ Pens- en darmfermentatie (methaan) } \\
\hline Melkkoeien & 5.5 & 50 & 2.7 & fokkerij, rantsoen en toevoegmiddelen \\
\hline Jongvee, vleeskalveren en stieren & 2.0 & 50 & 1.0 & fokkerij, rantsoen en toevoegmiddelen \\
\hline Varkens & 0.5 & 25 & 0.3 & rantsoenaanpassingen, afvangen \\
\hline Pluimvee & 0.0 & 0 & 0.00 & \\
\hline Overige diersoorten & 0.6 & 0 & 0.6 & \\
\hline Totaal & 8.5 & 45 & 4.7 & \\
\hline \multicolumn{5}{|l|}{ Mestmanagement (methaan) } \\
\hline Rundvee mestopslag & 2.1 & 75 & 0.5 & gescheiden verzameling, snelle afvoer, anaerobe opslag, afvangen \\
\hline Weidemest van graasdieren & 0.03 & 0 & 0.03 & \\
\hline Varkens mestopslag & 1.7 & 75 & 0.4 & gescheiden verzameling, anaerobe opslag, afvangen \\
\hline Pluimvee mestopslag & 0.07 & 75 & 0.02 & gescheiden verzameling, anaerobe opslag, afvangen \\
\hline Overige diersoorten mestopslag & 0.03 & 0 & 0.03 & \\
\hline Totaal & 3.9 & 74 & 1.0 & \\
\hline \multicolumn{5}{|l|}{ Lachgasemissies } \\
\hline Opslag mest (drijfmest en vaste mest) & 0.4 & 75 & 0.1 & gescheiden verzameling, anaerobe opslag, afvangen \\
\hline Weidemest van graasdieren & 0.9 & 0 & 0.9 & Nitrificatieremmers \\
\hline Toediening dierlijke mest & 1.3 & 50 & 0.7 & Nitrificatieremmers \\
\hline Toediening kunstmest & 1.6 & 75 & 0.4 & minder kunstmest, aangepaste meststoffen, nitrificatieremmers \\
\hline
\end{tabular}




\begin{tabular}{|c|c|c|c|c|}
\hline Breakdown OBKG NIR in Mton $\mathrm{CO}_{2}$ equivalenten & $\begin{array}{l}\text { Prognose } \\
2017\end{array}$ & $\begin{array}{l}\text { potentieel } \\
\text { reductie } \% \\
2050\end{array}$ & $\begin{array}{l}\text { Haalb } \\
\text { aar in } \\
2050\end{array}$ & Omschrijving maatregelen \\
\hline Toediening overig (zuiveringsslib en compost) & 0.00 & 0 & 0.00 & \\
\hline Landmanagement (Gewasresten en graslandvernieuwing) & 0.3 & 0 & 0.3 & \\
\hline Organische bodems & 0.8 & 25 & 0.6 & peilverhoging halveert oxidatie, maar verhoogt anaerobe omstandigheden \\
\hline Indirecte emissies & 0.9 & 40 & 0.5 & sterke daling $\mathrm{NH} 3$, toepassing nitrificatieremmers \\
\hline Totaal & 6.2 & 44 & 3.5 & \\
\hline \multicolumn{5}{|l|}{ Kalkmeststoffen } \\
\hline Toediening kalkmeststoffen & 0.07 & 0 & 0.07 & \\
\hline Totaal & 0.07 & 0 & 0.07 & \\
\hline Totaal & 18.8 & 51 & 9.3 & \\
\hline
\end{tabular}

34 | Wageningen Livestock Research Rapport 1133 


\section{Bijlage 2 Berekening broeikasgasemissies op keten niveau van de veehouderij in Nederland, gebaseerd op dieraantallen 2017}

De broeikasgasemissies in de gehele productieketen worden berekend aan de hand van het rekenprogramma FeedPrint, waarin voor de belangrijkste dierlijke sectoren de emissies van de gehele veevoer- en directe productieketen in beeld zijn gebracht. De berekeningen zijn ontleend aan FeedPrint, versie 2015.03.

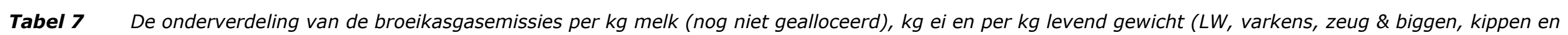
kalfsvlees).

\begin{tabular}{|c|c|c|c|c|c|c|c|c|c|}
\hline Onderdeel & Broeikasgas & $\begin{array}{l}\text { Melk\& } \\
\text { vlees }\end{array}$ & $\begin{array}{l}\text { Rund } \\
\text { vlees }\end{array}$ & Varken & $\begin{array}{l}\text { Zeug \& } \\
\text { biggen }\end{array}$ & Kip & Ei & Kalfsvlees rose & $\begin{array}{l}\text { Kalfsvlees } \\
\text { wit }\end{array}$ \\
\hline \multirow[t]{3}{*}{ Voerproductie } & $\mathrm{CH}_{4}$ & 11 & & 5 & 10 & 0 & 0 & 112 & 10 \\
\hline & $\mathrm{N}_{2} \mathrm{O}$ & 231 & & 490 & 511 & 302 & 321 & 668 & 304 \\
\hline & $\mathrm{CO}_{2}$ & 307 & & 1237 & 1870 & 1071 & 887 & 1943 & 1670 \\
\hline Dier & $\mathrm{CH}_{4}$ & 468 & & 121 & 63 & 0 & 0 & 318 & 412 \\
\hline \multirow[t]{2}{*}{ Mest } & $\mathrm{N}_{2} \mathrm{O}$ & 53 & & 130 & 199 & 72 & 78 & 260 & 83 \\
\hline & $\mathrm{CH}_{4}$ & 112 & & 885 & 1468 & 37 & 44 & 239 & 127 \\
\hline LULUCF & $\mathrm{CO}_{2}$ & 120 & & 880 & 1430 & 1790 & 1157 & 862 & 593 \\
\hline Overig(huisvesting) & $\mathrm{CO}_{2}$ & 60 & & 66 & 361 & 137 & 30 & 48 & 83 \\
\hline \multirow[t]{3}{*}{ Totaal } & totaal & 1362 & & 3814 & 5912 & 3409 & 2517 & 4451 & 3281 \\
\hline & OBKG & 875 & & 1631 & 2251 & 411 & 443 & 1598 & 935 \\
\hline & $\mathrm{CO}_{2}$ & 487 & & 2183 & 3662 & 2998 & 2074 & 2853 & 2346 \\
\hline NIR landbouw & & 829 & & 1234 & 1832 & 169 & 187 & 1085 & 743 \\
\hline rest van de keten (OBKG \& LULUCF) & & 166 & & 1277 & 1849 & 2032 & 1413 & 1375 & 785 \\
\hline rest van de keten $\left(\mathrm{CO}_{2}\right.$ energie $)$ & & 367 & & 1303 & 2232 & 1208 & 917 & 1991 & 1753 \\
\hline
\end{tabular}

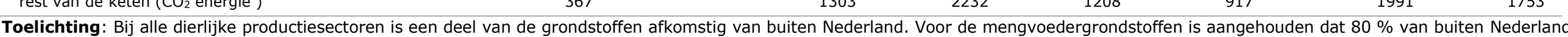

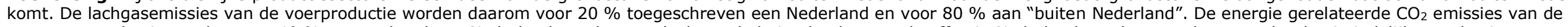
mengvoerproductie worden voor $40 \%$ toegerekend aan Nederland, omdat een deel van de buitenlandse grondstoffen in Nederland wordt verwerkt en omdat de uiteindelijke productie van

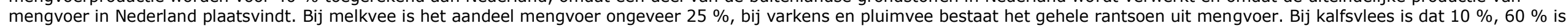

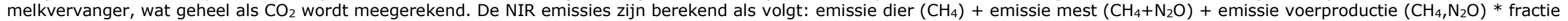

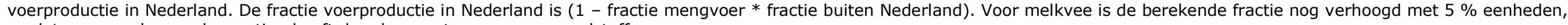
omdat gras een hogere bemesting heeft dan de meeste mengvoergrondstoffen. 


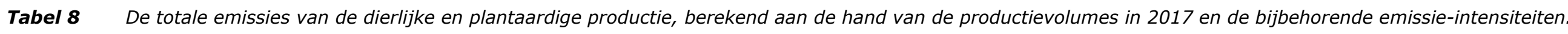

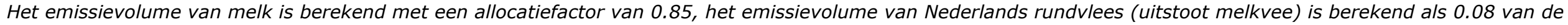
emissies van melkvee. De resterende 0.07 is bij de kalfsvlees productie meegerekend.

\begin{tabular}{|c|c|c|c|c|c|c|c|c|c|c|c|}
\hline Onderdeel & Broeikasgas & $\begin{array}{l}\text { Melk\& } \\
\text { vlees }\end{array}$ & $\begin{array}{l}\text { Rund } \\
\text { vlees }\end{array}$ & Varken & $\begin{array}{l}\text { Zeug \& } \\
\text { biggen }\end{array}$ & Kip & Ei & Kalfsvlees rose & $\begin{array}{l}\text { Kalfsvlees } \\
\text { wit }\end{array}$ & $\begin{array}{l}\text { Akker } \\
\text { bouw }\end{array}$ & Totaal \\
\hline Productievolume (kton) & & 14325 & $*$ & 2123 & 305 & 2022 & 688 & 162 & 293 & ** & \\
\hline Emissie volume keten (Mton) & & 19.51 & 1.84 & 8.10 & 1.80 & 6.89 & 1.73 & 0.72 & 0.96 & 1.99 & 43.54 \\
\hline Emissie volume NIR (Mton) & & 11.88 & 1.12 & 2.62 & 0.56 & 0.34 & 0.13 & 0.22 & 0.25 & 1.59 & 18.71 \\
\hline Emissie volume keten exclusief NIR (Mton) & & 7.63 & 0.72 & 5.48 & 1.25 & 6.55 & 1.60 & 0.50 & 0.71 & 0.40 & 24.83 \\
\hline Fractie mengvoer & $(-)$ & 0.25 & & 1.00 & 1.00 & 1.00 & 1.00 & 0.35 & 0.10 & & \\
\hline fractie em.N2O in NL & $(-)$ & 0.85 & & 0.20 & 0.20 & 0.20 & 0.20 & 0.80 & 0.80 & 1.00 & \\
\hline fractie em. $\mathrm{CO}_{2}$ in $\mathrm{NL}$ & $(-)$ & 0.93 & & 0.40 & 0.40 & 0.40 & 0.40 & 0.90 & 0.90 & 1.00 & \\
\hline Energie NL landbouw primair (Mton) & $\mathrm{CO}_{2}$ & 0.86 & 0.08 & 0.14 & 0.11 & 0.28 & 0.02 & 0.01 & 0.02 & 0.40 & 1.92 \\
\hline Energie veevoerketen binnen NL & $\mathrm{CO}_{2}$ & 4.09 & 0.38 & 1.05 & 0.23 & 0.87 & 0.24 & 0.28 & 0.44 & & 7.59 \\
\hline Energie veevoerketen buiten NL & $\mathrm{CO}_{2}$ & 0.31 & 0.03 & 1.58 & 0.34 & 1.30 & 0.37 & 0.03 & 0.50 & & 4.00 \\
\hline Lachgas ( \& methaan) veevoerketen buiten NL & $\mathrm{N}_{2} \mathrm{O}$ & 0.65 & 0.06 & 0.84 & 0.13 & 0.49 & 0.18 & 0.04 & 0.02 & & 2.41 \\
\hline LULUCF veevoerketen buiten NL & $\begin{array}{l}\mathrm{CO}_{2} / \\
\mathrm{N}_{2} \mathrm{O}\end{array}$ & 1.72 & 0.16 & 1.87 & 0.44 & 3.62 & 0.80 & 0.14 & 0.17 & & 8.91 \\
\hline Totaal emissies buiten NIR landbouw & & 7.63 & 0.72 & 5.48 & 1.25 & 6.55 & 1.60 & 0.50 & 0.71 & 0.40 & 24.83 \\
\hline
\end{tabular}




\section{Bijlage 3 Tabellen voor de inschatting van de implementatie van maatregelen}

\begin{tabular}{|c|c|c|c|c|c|}
\hline & & & $\begin{array}{l}\text { Scoren, bv: } \\
0=\text { nu al } \\
\text { kostendekkend, } \\
1=\text { kost geld, } \\
2=\text { kost veel } \\
\text { geld. }\end{array}$ & $\begin{array}{l}\text { Scoren, bv: } \\
0=\text { geen } \\
\text { weerstand, } \\
1=\text { weerstand, } \\
2=\text { veel } \\
\text { weerstand. }\end{array}$ & $\begin{array}{l}\text { Scoren, bv: } 0=\text { geen } \\
\text { aanpassingen } \\
\text { nodig, } \\
1=\text { aanpassingen } \\
\text { nodig, } 2=\text { veel } \\
\text { aanpassingen nodig }\end{array}$ \\
\hline Onderdeel & Mitigatiespoor & $\begin{array}{l}\text { TRL } \\
\text { niveau }\end{array}$ & $\begin{array}{l}\text { Maatsch. } \\
\text { Opgave - } \\
\text { Kosten }\end{array}$ & $\begin{array}{l}\text { Maatsch Opgave } \\
\text { Maatschappelijke } \\
\text { acceptatie } \\
\text { /weerstand }\end{array}$ & $\begin{array}{l}\text { Maatsch. Opgave - } \\
\text { Systeem } \\
\text { aanpassingen }\end{array}$ \\
\hline \multirow[t]{5}{*}{ 1.1.1 Pens en darmfermentatie (methaan) } & 1.1.1.1 Genetica & $1-3$ & 1 & 0 & 0 \\
\hline & 1.1.1.2 Additieven & $4-7$ & 1 & 1 & 0 \\
\hline & 1.1.1.3 Rantsoenaanpassing & 9 & $0-1$ & 0 & 0 \\
\hline & 1.1.1.4 Efficiëntie dieren & 9 & 0 & 0 & 0 \\
\hline & 1.1.1.5 Zero emission stal & $3-4$ & $1-2$ & $0-1$ & 1 \\
\hline \multirow[t]{2}{*}{ 1.1.2 Mestopslagen (methaan en lachgas) } & 1.1.2.1 Mest scheiden, luchtdicht opslaan, gas afvangen & 4 & 1 & 0 & 1 \\
\hline & 1.1.2.2 Zero emission stal & $3-4$ & $1-2$ & $0-1$ & 1 \\
\hline \multirow[t]{4}{*}{ 1.1.3 Mestaanwending en bodem (lachgas) } & 1.1.3.1 Nitrificatieremmers & 7 & 1 & 2 & 0 \\
\hline & 1.1.3.2 Vlinderbloemigen & 9 & 1 & 0 & 1 \\
\hline & 1.1.3.3 Andere kunstmestsoorten & 9 & 1 & 0 & 1 \\
\hline & 1.1.3.4 Efficiëntie bemesting & $7-9$ & $0-1$ & 0 & 0 \\
\hline
\end{tabular}




\begin{tabular}{|c|c|c|c|c|c|}
\hline & & & $\begin{array}{l}\text { Scoren, bv: } \\
0=n u \text { al } \\
\text { kostendekkend, } \\
1=\text { kost geld, } \\
2=\text { kost veel } \\
\text { geld. }\end{array}$ & $\begin{array}{l}\text { Scoren, bv: } \\
0=\text { geen } \\
\text { weerstand, } \\
1=\text { weerstand, } \\
2=\text { veel } \\
\text { weerstand. }\end{array}$ & $\begin{array}{l}\text { Scoren, bv: } 0=\text { geen } \\
\text { aanpassingen } \\
\text { nodig, } \\
1=\text { aanpassingen } \\
\text { nodig, } 2=\text { veel } \\
\text { aanpassingen nodig }\end{array}$ \\
\hline \multirow[t]{5}{*}{ 1.3.1 LULUCF Landbouw gerelateerd } & 1.3.1.1 Onderwaterdrainage & 6 & 1 & 1 & 1 \\
\hline & 1.3.1.2 Peilverhoging & 8 & 1 & 1 & 1 \\
\hline & 1.3.1.3 Veengrond uit productie nemen & $6-9$ & 2 & 1 & 2 \\
\hline & 1.3.1.4 $\mathrm{C}$ vastlegging op minerale gronden & $7-9$ & $0-1$ & 0 & 1 \\
\hline & 1.3.1.5 Agroforestry & 5 & 1 & 0 & 1 \\
\hline \multirow[t]{2}{*}{ 1.3.2 LULUCF Natuur } & 1.3.2.1 Bosaanplant & 9 & 2 & 1 & 2 \\
\hline & 1.3.2.2 Klimaatslim bosbeheer & 7 & 1 & 0 & 1 \\
\hline 2.1.1 Energiegebruik NL landbouw & Elektrificatie landbouwmachines & 4 & 1 & 0 & 1 \\
\hline 2.2.1 Kunstmestproductie (voor NL gebruik) ( $\mathrm{CO}_{2}$ en lachgas) & Energieneutraal kunstmest produceren & $7-9$ & 1 & 0 & 0 \\
\hline 3.1.1 Teelt voergrondstoffen $\left(\mathrm{CO}_{2}\right.$, methaan en lachgas $)$ & Reductie broeikasgassen elders in en buiten Europa & 5 & 2 & 2 & 2 \\
\hline 3.1.2 Kunstmestproductie (voor NL gebruik) ( $\mathrm{CO}_{2}$ en lachgas) & Energieneutraal kunstmest produceren & $7-9$ & 1 & 0 & 0 \\
\hline 3.1.3 Teelt voergrondstoffen (LULUCF) & Europese mengvoedergrondstoffen & 9 & 0 & 0 & 2 \\
\hline \multirow[t]{2}{*}{ 4.1.1 Energieproductie } & 4.1.1.1 Zonneweides & $8-9$ & 1 & 1 & 2 \\
\hline & 4.1.1.2 Windturbines & 9 & 1 & 2 & 2 \\
\hline
\end{tabular}




\title{
Bijlage 4 Efficiëntieverbetering in de Nederlandse veehouderij
}

\author{
Melkveehouderij \\ De melkveehouderij loopt momenteel voorop bij de reductie van broeikasgassen en zet nog steeds \\ sterk in op de verdere verbetering van de efficiëntie. De sectorrapportage (Doornewaard et al., 2018) \\ laat zien dat er nog veel spreiding aanwezig is bij melkveebedrijven, hetgeen betekent dat voor veel \\ boeren nog een verbetering haalbaar is. \\ $\mathrm{Er}$ is in de huidige melkveehouderij nog wel enige ruimte om de emissies te verminderen. De \\ sectorrapportage (Doornewaard et al., 2018) laat zien dat er sprake is van een bandbreedte in de \\ emissies: bij een gemiddelde emissie van $1.15 \mathrm{~kg} \mathrm{CO}_{2}$ equivalenten per $\mathrm{kg}$ melk in 2016 bevindt $50 \%$ \\ van de bedrijven zich in het traject van $1.10-1.25 \mathrm{~kg}$, terwijl $90 \%$ van de bedrijven zich in het \\ traject bevindt van $0.98-1.57 \mathrm{~kg} \mathrm{CO} 2$ equivalenten. Door verbetering van de bedrijfsvoering valt bij \\ een deel van de bedrijven nog wel winst te halen. \\ De verbetering van de efficiëntie richt zich vooral op de verbetering van de voerbenutting via een \\ hogere melkproductie en een langere levensduur per koe en op de verbetering van de netto productie \\ van gras- en bouwland door efficiëntere bemesting en minder oogst- en conserveringsverliezen. Naast \\ maatregelen die gericht zijn op efficiëntie, zijn er maatregelen die zich richten op een lager gebruik \\ van energie en rantsoenveranderingen die de productie van methaan uit de pens verminderen. \\ De verbetering van de efficiëntie is vaak een kosteneffectieve strategie (Van den Pol et al., 2013). Het \\ is daarnaast een aansprekende strategie die appelleert aan een gevoel van trots over de efficiënte \\ bedrijfsvoering en de hoge benutting van mineralen. Tegelijkertijd vergt deze strategie veel van de \\ vaardigheden van de veehouder. Dat wordt steeds sterker, want in de afgelopen $20-25$ jaar is veel \\ van het laaghangend fruit wel geplukt. Hoewel de efficiëntie-strategie succesvol is gebleken in de \\ afgelopen jaren, verwachten we dat de reductie die daarmee bereikt kan worden niet genoeg is om de \\ gestelde doelen te bereiken. We denken dat een andere strategie ingezet moet worden om \\ verdergaande emissiereducties te bereiken. \\ Het huidige palet aan mitigatiemaatregelen bestaat voor een aanzienlijk deel uit maatregelen die \\ neerkomen op het beter aansluiten bij de Goede Landbouw Praktijk. Slechts een beperkt aantal \\ maatregelen richt zich op andere aspecten, zoals de monomestvergisting en de introductie van \\ klavers. De monomestvergisting is een maatregel met hoge kosten en zal naar verwachting weinig \\ worden toegepast. Hoewel er geen gedetailleerde berekeningen zijn gedaan zal de gemiddelde \\ reductie van de emissies per $\mathrm{kg}$ melk in de buurt van de $20 \%$ liggen, voor het ene bedrijf wat meer, \\ voor het andere wat minder. Dat betekent dat de ondergrens van de emissies ergens in de buurt van \\ de $0.95 \mathrm{~kg} \mathrm{CO}_{2}$ equivalenten per kg melk kan uitkomen. \\ Bij een melkvolume van 14 Megaton zal de emissie van alleen al de melkveehouderij uitkomen in de \\ buurt van de 13 Megaton $\mathrm{CO}_{2}$ equivalenten, wat al ruimschoots meer is dan de 11.2 Megaton die als \\ bovengrens voor Nederland is genoemd.
}

\section{Varkenshouderij}

De broeikasgasemissies per kilogram varken zijn gedaald van 5.4 naar $3.2 \mathrm{~kg} \mathrm{CO} 2$ equivalenten per $\mathrm{kg}$ levend gewicht (LW) tussen 1990 en 2012 (Kuling en Blonk, 2016). Ook hier ligt de belangrijkste redenen voor de daling in een combinatie van een lagere voederconversie voor fokzeugen en vleesvarkens en een sterke daling van de ammoniakemissie. De stijging van het aantal levend geboren biggen per worp heeft bijgedragen aan de lagere voederconversie.

De varkenshouderij kent al een lange trend van beter wordende voerefficiëntie, alhoewel er rond het jaar 2000 een korte periode van verslechtering optrad (Figuur 5). De voerconversie in 2014 is ongeveer $3 \%$ beter dan die in het jaar 2000. Op basis van dierproeven verwachten Kuling en Blonk (2016) een verdere daling van de voederconversie (Tabel 9) 
Tabel 9 Historisch verloop en verwachte trends in de voederconversie voor vleesvarkens, fokzeugen en vleeskuikens.

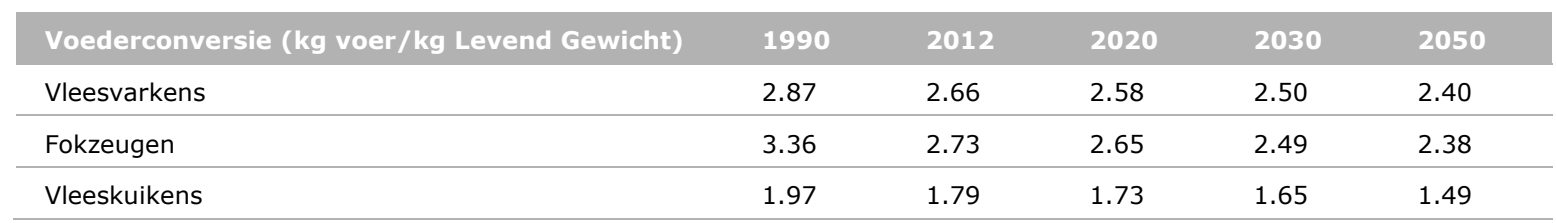

Het nieuwe onderzoekprogramma van de Publiek Private Samenwerking Feed4Foodure heeft de ambitie neergezet om de benutting van $\mathrm{N}$ en $\mathrm{P}$ in de voeding van varkens en pluimvee nog met 5 procentpunten te verbeteren. Daarbij wordt gedacht aan een combinatie van betere voeding via betere grondstoffen (meer primaire producten) en voeding op individueel niveau, betere diergezondheid en genetische vooruitgang.

Door de betere voederconversie, grootschalige toepassing van luchtwassers, energiebesparing en betere efficiëntie in de slachterijen is de verwachting dat de footprint van varkensvlees nog met $1.6 \mathrm{~kg}$ kan dalen tot $1.6 \mathrm{~kg} \mathrm{CO} 2$ equivalenten per kg LW (Kuling en Blonk, 2016), waarvan $1 \mathrm{~kg}$ daling voortkomt uit de betere voederconversie. Het is niet bekend in hoeverre de daling van emissies door een betere voederconversie wordt tegengewerkt door de trend om meer primaire producten en speciale grondstoffen te gebruiken. Beide groepen voedermiddelen hebben doorgaans een hogere emissie per kg product dan bijproducten. De verdere verwachte daling van de broeikasgasemissies $\mathrm{kg}$ $\mathrm{CO}_{2}$ equivalenten per $\mathrm{kg} \mathrm{LW}$ komt voort uit volledige toepassing van luchtwassers, energiebesparing en -productie.

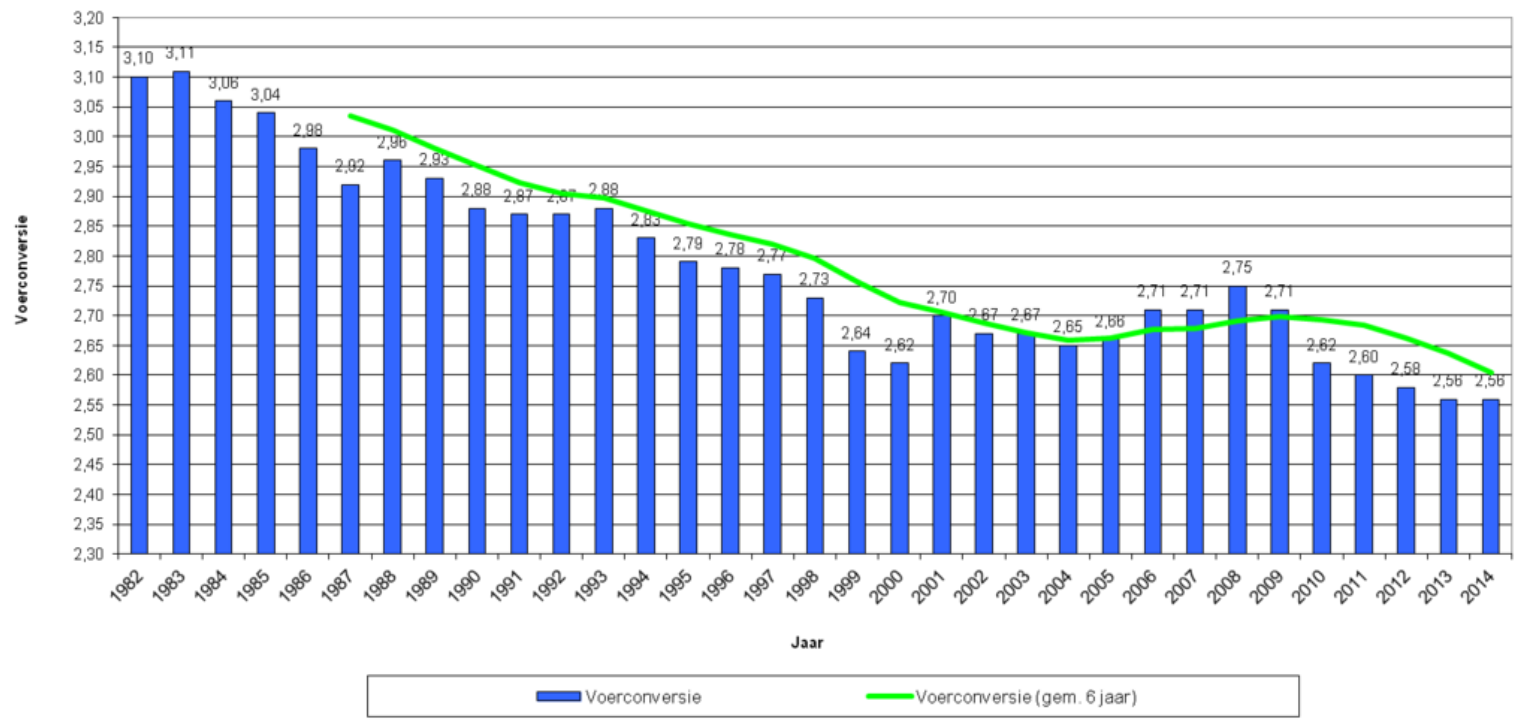

Figuur $5 \quad$ Het verloop van de voederconversie van vleesvarkens van 1982 - 2014 Bron: Agrovision. https://www.agrovision.nl/sectoren/varkenshouderij/pigbusiness/

\section{Pluimveehouderii}

Vleeskuikens

De voederconversie in de vleeskuikenhouderij is in de afgelopen 30 jaar sterk verbeterd (Tabel 9). De verwachting is dat deze trend nog doorzet, Kuling en Blonk (2016) hanteren eenzelfde reductie van de voederconversie voor de komende dertig jaar als in de afgelopen periode. De introductie van de trager groeiende kip zorgt echter voor een toename van de voederconversie. Deze is nog niet meegenomen in de genoemde trend en toekomstverwachting. In de gegevens van de boekhoudbedrijven van Wageningen Economic Research (www.agrimatie.nl) is vanaf 2014 weer een lichte stijging van $3 \%$ waar te nemen in de voerhoeveelheid per $\mathrm{kg} \mathrm{LW}$. Als het aandeel langzaam groeiende dieren in de Nederlandse productie toeneemt, zal een verdere daling van de voederconversie beperkt blijven. Kramer en Blonk (2015) gaan op aangeven van een aantal onderzoekers zelfs uit van een stijgend voerverbruik voor vleeskuikens. Deze stijgende voederconversie is niet opgenomen in de lange termijn verwachting van Kuling en Blonk (2016). 
Door de betere voederconversie, grootschalige toepassing van luchtwassers, energiebesparing en betere efficiëntie in de slachterijen is de verwachting dat de footprint van kippenvlees nog met $1.1 \mathrm{~kg}$ kan dalen tot $1.0 \mathrm{~kg} \mathrm{CO} 2$ equivalenten per kg LW (Kuling en Blonk, 2016). Daarvan is $0.5 \mathrm{~kg}$ afkomstig van een verbetering van de voederconversie. Ook hier geldt dat het niet bekend is in hoeverre de daling van emissies door een betere voederconversie wordt tegengewerkt door de trend om meer primaire producten en speciale grondstoffen te gebruiken. Daarnaast is de verwachting over een verder dalende voederconversie mogelijk te optimistisch. Net als bij de varkenshouderij, komt de verdere verwachte daling van de broeikasgasemissies $\mathrm{kg} \mathrm{CO}_{2}$ equivalenten per $\mathrm{kg} \mathrm{LW}$ voort uit volledige toepassing van luchtwassers, energiebesparing en -productie.

\section{Leghennen}

Van leghennen zijn geen lange termijn data bekend. De gegevens van legpluimvee bedrijven die worden verzameld door Wageningen Economic Research laten geen verbetering zien van de voederconversie en vanaf 2014 treedt er weer een lichte stijging op. Kramer en Blonk (2015) gaan op aangeven van een aantal onderzoekers zelfs uit van een stijgend voerverbruik voor leghennen. De daling van de footprint door het gebruik van restproducten (www.kipster.nl) kan worden gerealiseerd bij een berekening op het niveau van individuele bedrijven. Aangezien deze restproducten al volop worden gebruikt en verbetering van de voeding een tendens inhoudt naar meer primaire en speciale producten, zal een daling van de footprint van mengvoeders weinig waarschijnlijk zijn. Als vergelijkbare ontwikkelingen plaatsvinden in de leghennenhouderij als in de houderij van varkens en vleeskuikens, zal de footprint van eieren nog kunnen dalen door de inzet van luchtwassers, besparing en productie van energie. 

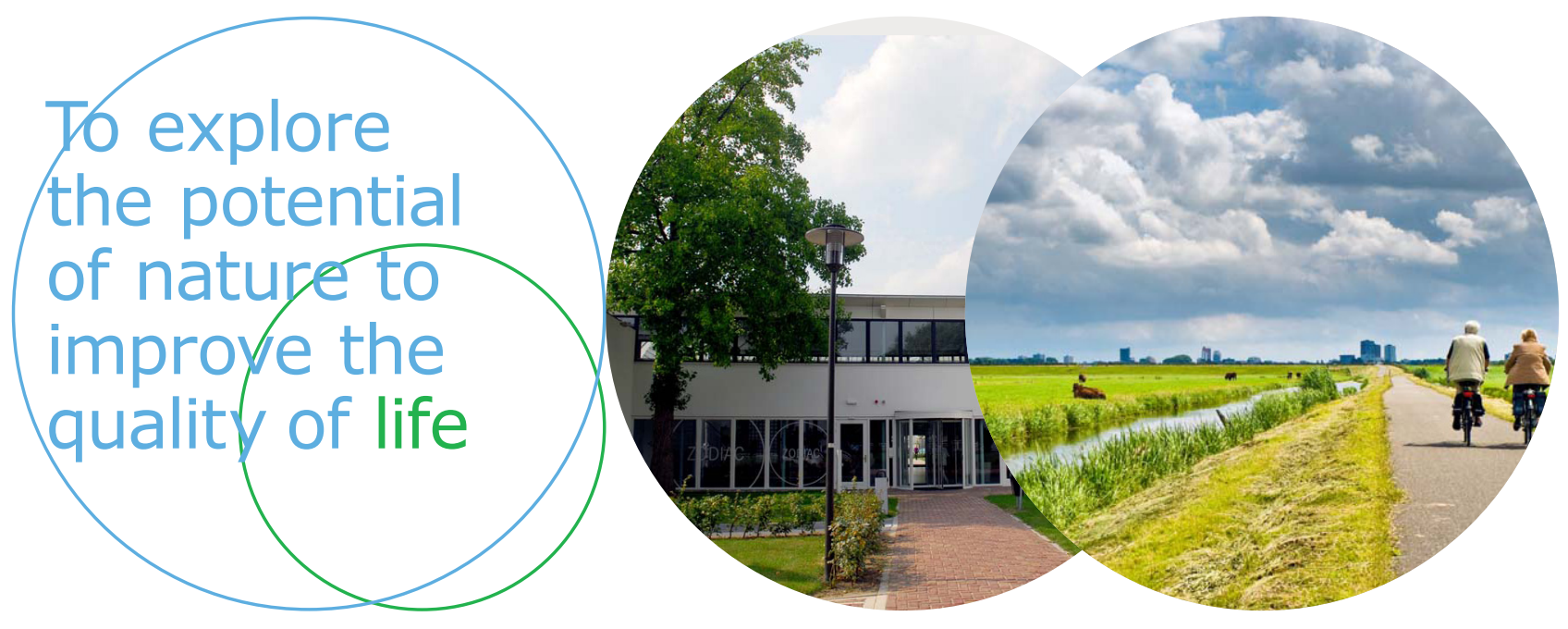

Wageningen Livestock Research Postbus 338

Wageningen Livestock Research ontwikkelt kennis voor een zorgvuldige en $6700 \mathrm{AH}$ Wageningen

T 0317483953

renderende veehouderij, vertaalt deze naar praktijkgerichte oplossingen en innovaties, en zorgt voor doorstroming van deze kennis. Onze wetenschappelijke E info.livestockresearch@wur.nl www.wur.nl/ livestock-research kennis op het gebied van veehouderijsystemen en van voeding, genetica, welzijn en milieu-impact van landbouwhuisdieren integreren we, samen met onze klanten, tot veehouderijconcepten voor de $21 \mathrm{e}$ eeuw.

De missie van Wageningen University \& Research is 'To explore the potential of nature to improve the quality of life'. Binnen Wageningen University \& Research bundelen 9 gespecialiseerde onderzoeksinstituten van Stichting Wageningen Research en Wageningen University hun krachten om bij te dragen aan de oplossing van belangrijke vragen in het domein van gezonde voeding en leefomgeving. Met ongeveer 30 vestigingen, 6.500 medewerkers en 10.000 studenten behoort Wageningen University \& Research wereldwijd tot de aansprekende kennisinstellingen binnen haar domein. De integrale benadering van de vraagstukken en de samenwerking tussen verschillende disciplines vormen het hart van de unieke Wageningen aanpak. 